\title{
8-12 Yaş Aralığındaki Öğrencilerin Mantıksal Düşünme Becerileri Üzerine Bir
}

\section{Araştırma}

\section{Derya CAN*, Hülya ALTUNYA**, Veli CAN**}

Öz: Doğru düşünme kural ve formlarının bilgisi ya da düşünme yasalarının bilimi olarak tanımlanan mantık, öğrencilere doğru düşünmenin öğretilmesi konusunda başvurulması gereken alanlardan birisi olarak karşımıza çıkmaktadır. Mantıksal düşünme becerisinin gelişimi ve desteklenmesi için mantık biliminin uygulamalarını içeren akıl ilkelerinin ve akıl yürütme yöntemlerinin bir araç olarak kullanılması oldukça önemlidir. Bu araştırmada, ilkokul ve ortaokul öğrencilerinin mantıksal düşünme becerilerinin yaş ve sınıf düzeyi değişkenlerine göre nasıl değiştiğinin incelenmesi amaçlanmıştır. Bu çerçevede ilgili alan yazın taraması sonrası öğrencilerin mantıksal düşünme becerilerini ölçmeye yönelik bir test geliştirilmiş ve pilot uygulama sonrasında geçerlik ve güvenirlik çalışmaları tamamlanmıştır. Analizler sonucunda 18 madde ve 4 boyuttan oluşan bir yapı elde edilmiş ve ortaya çıkan yapının geçerli bir uyum iyiliğine sahip olduğu görülmüştür. Araştırma sonucunda, öğrencilerin mantıksal düşünme becerilerinin mantık testinde yer alan alt boyutlara göre farklılaştı̆̆ 1 tespit edilmiştir. Ayrıca öğrencilerin yaşları ve sınıf düzeyleri arttıkça mantıksal düşünme becerilerini yansıtan performansları da artmıştır. Öğrencilerin erken yaşlardan itibaren sistematik düşünme, akıl yürütme, çıkarımda bulunma gibi becerilerini desteklemek amacıyla mantık eğitiminin belli bir ders kapsamında ve formel mantık bilgisini içerecek şekilde verilmesi önerilmektedir.

Anahtar Kelimeler: Mantık, mantıksal düşünme, mantıksal düşünme yeteneği testi.

\footnotetext{
*Arş. Gör. Dr., Mehmet Akif Ersoy Üniversitesi, Eğitim Fakültesi, Sınıf Eğitimi ABD, Email:deryacakmak@mehmetakif.edu.tr, Orcid No: 0000-0003-1257-8793

** Doç. Dr., Süleyman Demirel Üniversitesi, İlahiyat Fakültesi, Mantık ABD, Email: hulyaaltunya@sdu.edu.tr, Orcid No: 0000-0003-2115-5207

*** Bilim Uzman1-Felsefe Öğretmeni, Burdur Anadolu İmam Hatip Lisesi, Email: okyanuscan15@gmail.com, ORCID:00000003-3025-5875
}

\begin{tabular}{lll}
\hline Gönderim: 10.04.2019 Kabul:27.06.2019 $\quad$ Yayın: 15.09.2019 & Kab
\end{tabular}




\title{
A Research on the Logical Thinking Skills of 8-12 Old-Students
}

\begin{abstract}
The logic, which is defined as the knowledge of correct thinking rules and forms or the science of thinking laws, is one of the areas to be applied in order to teach correct thinking ways to the students. It is important to use the principles of questioning and reasoning methods as a tool for the development and support of logical thinking. In this study, it is aimed to examine how the logical thinking skills of primary and secondary school students change according to variables of age and grade level. After the related literature was reviewed, with this aim a test was developed to measure the students' logical thinking skills and the validity and reliability studies were completed following the pilot implementation. As a result of the analyses, a structure consisting of 18 items and 4 dimensions was obtained and it was found that final structure had a valid goodness of fit. The findings indicate that the students' logical thinking skills differ based on the sub-dimensions of the logic test. Also, as students' ages and class levels increased, their performance reflecting logical thinking skills increased. In order to support students' systematic thinking, reasoning and inference skills from an early age, it is suggested that logic education should be given within the scope of a specific course in a manner to cover formal logic knowledge.
\end{abstract}

Keywords: Logic, logical thinking, logical thinking test.

\section{Giriş}

Eğitim alanında farklı teoriler ortaya atan araştırmacılar ve eğitimciler 40 yılı aşkın süredir öğrencilere doğrudan bilgiyi öğretmekten daha çok, o bilginin nasıl ortaya çıktığının öğretilmesi gerektiğine vurgu yapmışlardır (Boyd, 2015; Cam, 2014; Lipman, 1973). Özellikle küçük yaş grubundaki çocuklara okullarda ana dil, matematik, fen bilimleri, beden eğitimi, sanat, müzik, yabancı dil gibi alanlarda öğretim yapılırken genel düşünme becerilerinin öğretimi konusunda da bir dersin bulunması gerektiği vurgulanan noktalar arasındadır (Baroody, Purpura, Eiland, \& Reid, 2015). Çünkü çocuklara birtakım eylemlerimizin, davranışlarımızın doğruluğu ya da yanlışlığı öğretilmeye çalış1lırken düşüncelerimizin doğruluğu ya da yanlışlığı üzerinde de durulması bu çağın gerekliliğini oluşturmaktadır (Säre, Luik \& Tulviste, 2016).

21. yüzyıl yetkinlikleri sorgulayıcı araştırma, tartışma, yaratıcı düşünme, istatistiksel düşünme, kodlama dilini kullanma, sistemsel düşünme gibi birtakım becerileri gerektirmektedir (Aydeniz, 2017). Özellikle STEAM (Fen, Teknoloji, Mühendislik, Sanat ve 
Matematik) uygulamalarının bu becerileri desteklediği görüşü hâkimdir. Ancak öğrencilere bu becerilerin kazandırılabilmesi için öncelikle doğru düşünmenin ilke ve yöntemlerinin öğretilmesi gerekmektedir. Doğru düşünme kural ve formlarının bilgisi ya da düşünme yasalarının bilimi olarak tanımlanan mantık, öğrencilere doğru düşünmenin öğretilmesi konusunda başvurulması gereken alanlardan birisi olarak karşımıza çıkmaktadır (Özlem, 2012). Öğrencilerin akıl yürütme becerilerini desteklemeye yönelik bilgi, beceri ve stratejiler geliştirmesini sağlamak için neden mantık biliminin bir araç olarak seçildiği hem bir disiplin olarak hem de bir düşünme biçimi olarak mantığın ne olduğunun açıklanması ile mümkündür. Mantık bir disiplin veya bir ders adı olarak kullanılmakla birlikte aynı zamanda bir düşünme biçimidir. Mantık bilimi, mantıklı düşünmenin kural ve yasalarını ortaya koyan bir disiplindir (Öner, 1982, s.2-3; Akt: Emiroğlu, 2012). Terim olarak mantık uygulamada iki anlama sahiptir (Özlem, 2012, s.27). İlk anlamı mantıksal düşünme adı verilen bir düşünme türünün ve tarzının adıdır. İkinci anlamı ise düzgün düşünme ya da mantıksal düşünme denilen düşünme türünü ve tarzını konu edinen felsefe disiplinin adıdır (Özlem, 2012). Özlem (2012) mantık terimiyle ilgili karışıklığı gidermek için mantık teriminin bir felsefe disiplininin adı olarak kullanılabileceğini, bu disiplinin konusunun ise düzgün düşünme, mantıksal düşünme, akıl yürütme, argümantasyon gibi terimlerle ifade edilebileceğini belirtmiştir. Mantık, her tür düşünme ile değil, mantıksal düşünme, akıl yürütme, usavurma, argümantasyon şeklinde de isimlendirilen düşünme türünün formuyla ilgilenir (Özlem, 2012). Bu araştırma kapsamında mantık kavramının işlevsel tanımı, akıl yürütmelerin doğruluğunu (geçerliliğini) sağlayan kuralları ortaya koyma özelliği ile tanımlanmakta olup mantıksal düşünme ya da akıl yürütme terimleriyle ifade edilmiştir.

Mantıksal düşünme becerisinin gelişimi ve desteklenmesi için mantık biliminin uygulamalarını içeren akı1 ilkelerinin (özdeşlik, çelişmezlik, üçüncü halin imkânsızlığı), akıl yürütme yöntemlerinin (dedüksiyon, endüksiyon, analoji), kavram ve terim, önerme, sınıflama (tasnif), çıkarım ve kıyasların bir araç olarak kullanılması oldukça önemlidir. Örneğin, kıyas, mantıksal düşünme becerisinin gelişimini destekleyen önemli bir araçtır (Özlem, 2012). “Bütün insanlar ölümlüdür.”, "Sokrates insandır." öncüllerinden "O halde, Sokrates ölümlüdür." sonucunun çıkarılabilmesi mantıksal düşünmeyi destekleyen bu aracın doğru kullanılabilmesi ile mümkündür. Kıyasın ne olduğunu ve nasıl yapıldığını bilen öğrenciler, örneğin matematik dersinde, " $0,2,4,6$ ve 8 ile biten bütün sayılar çifttir." ve " 10 ile tam olarak bölünebilen bütün sayıların sonu 0'dır." öncüllerinden yola çıkarak "O halde 10 ile tam bölünebilen bütün sayılar çift sayıdır." sonucuna ulaşabilir. Ya da "Bütün eşkenar dörtgenlerin 
dört eş kenarı olmak zorundadır.", "Bütün karelerin dört eş kenarı olmak zorundadır." ve “Bütün karelerin dört dik açısı olmak zorundadır.” öncüllerinden yola çıkarak "Bütün kareler eşkenar dörtgendir." ve "Bütün eşkenar dörtgenler karedir." sonuçlarından hangisine ulaşılabileceği üzerinde akıl yürütüp tartışabilirler. Bu da öğrencilerin bazı kavramların ve kuralların nedenlerini anlayıp kavramsallaştırmasını sağlar. Bu örneklerde de görüldüğü gibi matematik mantığın kanıtlamacı (dedüktif) yöntemini kendi evrenine uygulayan bir disiplin olup uygulamalı mantığın önemli örneklerinden birisini oluşturmaktadır (Özlem, 2012). Burada mantığın uygulama alanlarına kısaca değinmenin önemli olduğunu düşünmekteyiz. Mantık pratik alanda insana eleştirel düşünme, akılcı tartışma, sorular sorma ile var olan bilgileri ve işleri pratik-sezgisel bir şekilde öğrenmeyi sağlar. Ayrıca her çeşit bilimin, matematik gibi formel bilimlerin olduğu kadar, fizik gibi gündelik bilimlerin, doğa bilimlerinin ve mühendislik bilimlerinin, sosyal bilimlerinin temellendirilmesinde gittikçe artan bir ölçüde mantığa ihtiyaç duyulmaktadır. Teknik alanda ise özellikle her türlü elektrik devrelerinin, elektronik beyinlerin (bilgisayar, hesap makinesi ve ak1ll telefonlar gibi) teorisine uygulanması açısından önemlidir.

Günlük yaşamda ve farklı disiplinlerde uygulama olanağı olan ve doğru düşünmenin kural ve yasalarını ortaya koyan bir disiplin olarak mantık bilimine Türkiye'de ne kadar ve nasıl yer verildiğinin ortaya konulması önem taşımaktadır. Türkiye'de ortaöğretim düzeyinde Mantık Dersi Öğretim Programı (2009) yer almakta olup program kapsamında doğru düşünme yollarını günlük yaşama aktarabilen, tutarlı düşünen, çelişkileri fark eden, bağımsız düşünebilen, karşılaştığı problemlere çözümler üretebilen bireyler yetiştirilmesi hedeflenmektedir (MEB, 2009). Bu hedeflerin 21. yy becerileri olarak isimlendirilen eleştirel düşünme, problem çözme, bilgi ve teknoloji okuryazarlığı, kodlama becerisi gibi günün koşullarına göre değişim gösteren becerilerle ilişkisi dikkat çekmektedir (European Commission, 2014; Partnership for 21st Century Skills, 2009). Örneğin mantıksal akı1 yürütmenin bir parçası olarak görülen kodlama becerisi (European Commission, 2014) ulusal ve uluslararası düzeyde önemli bir yetkinlik haline gelmiş olup okullarda öğretim programlarına bu konunun dâhil edilmesi için çalışmalar yürütülmektedir (Balanskat \& Engelhardt, 2014). Türkiye’de ise 2012-2013 öğretim y1lından itibaren Bilişim Teknolojileri ve Yazılım dersinin 5. sınıflardan başlayarak verilmesi ve ders kapsamında sosyal kodlama ortamlarının kullanılması tavsiye edilmiştir (MEB-TTKB, 2015). Bu becerilerin desteklenmesi gerekliliğine vurgu yapılan bir diğer nokta 2023 Eğitim vizyonu olup, vizyon belgesinde kodlama, elektronik tasarım gibi birtakım üretim becerilerinin ilkokul döneminden itibaren 
öğrenme süreçlerine entegrasyonunun sağlanması gerektiği belirtilmiştir (2023 Eğitim Vizyonu). Ayrıca 2023 Eğitim Vizyonu'nda eğitim sistemindeki tüm sınavların amacı, içeriği, soru tiplerine bağlı yapısı ve sağlayacağı yarar bakımından yeniden düzenlenmesi planlanmış; akıl yürütme, eleştirel düşünme, tahmin etme, yorumlama ve benzeri zihinsel becerilerin sınanmasının ön plana çıkarılacağı belirtmiştir. 2018-2019 öğretim yılı ortaöğretim kurumlarına ilişkin merkezi sınava yönelik örnek sorular incelendiğinde (bknz, http://odsgm.meb.gov.tr/) soruların niteliğinin mantıksal düşünme ve akıl yürütme becerilerini ölçmeye yönelik boyut kazandığı dikkat çekmektedir. Tüm bu gelişmeler mantıksal düşünme ve akıl yürütme becerilerinin gelişiminin erken yaşlardan itibaren başlanarak desteklenmesi gerekliliğini ortaya koymaktadır.

Çocuklarda mantıksal düşünme becerisinin ne zaman gelişmeye başladığ yapılan çalışmalar incelendiğinde bu konuda farklı görüşlere rastlanmaktadır (Galotti, Komastu \& Volez, 1997; Hawkins, Pea, Glick ve Scribner, 1984; Markovits, Schleiffer \& Fortier, 1989; Moshman \& Franks, 1986; Piaget, 1966; Richards ve Sanderson, 1999). Bir grup araştırmacı, mantıksal düşünmenin temelini oluşturan kavram oluşturma ve sınıflandırma becerilerinin bebeklikten itibaren gelişmeye başladığını savunmaktadır (Mandler \& McDonough, 1993; Quinn \& Eimas, 1996). Kavram oluşturmaya ilişkin ilerlemelerin Piaget gibi daha önceki kuramcıların söylediğinden, daha erken ortaya çıktığını savunan araştırmacılara göre (Munakata, Casey \& Diamond, 2004; Spelke \& Kinzler, 2009) kavram oluşumu ve sınıflandırma bebeklikten itibaren gelişim göstermektedir. Örneğin 9-11 aylık bebeklerle yapılan çalışmada; nesneler algısal olarak benzer olmasına rağmen -uçaklar ve kuşlar kanatlıdır- bebekler kuşları hayvanlar, uçakları araçlar olarak sınıflandırmıştır (Mandler \& McDonough, 1993).

Piaget'e göre çocuklar 4-7 yaşlarını kapsayan sezgisel düşünce alt evresinde akıl yürütmeye başlarlar. Ancak somut işlemler döneminde (7-11 yaş) somut örneklere uygulanabilir olduğu sürece mantıklı muhakeme yapabilirler. $\mathrm{Bu}$ dönemin ayırt edici özelliklerinden birisi, nesneleri farklı gruplara ve alt gruplara ayırma ve bu grupların kendi aralarındaki bağlantılarını göz önünde bulundurmayı sağlayan sınıflandırma becerisidir. Piaget geçişlilik özelliğinin de bu dönemde gerçekleştiğini savunarak farklı uzunluklardaki üç çubuktan (A-uzun, B-ortanca, C-kısa) A'nın B'den, B'nin de C'den uzun olduğu durumunu göz önünde bulundurarak A'nın C'den uzun olduğu çıkarımını somut işlemler dönemindeki çocukların yapabileceğini savunur. Ancak bazı araştırmacılar (Holzman, 2009; Irvıne \& Berry, 
2010; Akt: Santrock, 2012) eğitim ve kültürün Piaget'nin bilişsel gelişim evrelerini farklı şekilde etkileyeceğini düşünmekte ve işlem öncesi dönem çocuklarının somut işlemler dönemindeki muhakemeyi yapabilmek üzere eğitilebileceğini savunmaktadır.

Piaget bilişsel gelişimi evrelere ayırmış olup mantıksal düşünme becerisinin somut işlemler ve soyut işlemler evrelerinde görüldüğünü belirtmektedir. Piaget'e göre çocuklar 7-8 yaşlarında mantıksal akıl yürütme becerisi kazanmaya başlamakta olup bu beceri çocukların kişisel gerçeklik kavramıyla ilgili olarak gelişmeye devam etmektedir (Piaget, 1966, s.67). Yani küçük yaştaki çocuklar kendi yaşantılarında gereklilik duyduklarında ve somut problemlerin çözümünde çıkarımda bulunmaktadırlar. Piaget formel çıkarımsal akıl yürütme becerisinin gelişiminin 11-12 yaşlarında soyut işlemler döneminde başlayarak yetişkinliğe kadar devam ettiğini belirtmiştir. Bu nedenle, Piaget tarafindan ortaya atılan bu teori 12 yaşından önce çocukların çıkarımsal akıl yürütme yapamayacağını ortaya koymaktadır (Piaget, 1966). Piaget'nin teorisini destekleyen birçok çalışma yapılmıştır. Örneğin, Markovits, Schleiffer ve Fortier (1989) çocuklarda çıkarımsal akıl yürütmenin gelişimini anahatlarıyla belirtmişlerdir. Markovits ve arkadaşları tarafından yapılan çalışmada anaokulundan 5. sınıfa kadar 85 çocukla çalışılmıştır. Çalışmada önermelerden sonuç çıkarmayı gerektiren kıyaslar kullanılmış olup kıyasların bir kısmı mantıksal bir kısmı ise mantık dışı sonuçlara ulaşmayı sağlayacak niteliktedir. Çocuklara önermelerden elde edilen sonuçların geçerliliği ve buna nasıl ulaştıkları sorulduğunda, mantıksal çıkarımlara verilen doğru yanıt oranının oldukça yüksek olduğu görülmüştür (Markovits ve diğ., 1989). Ayrıca 6-8 yaş aralığındaki çocukların yaşı arttıkça mantık dışı sonuçları tanımlama becerilerinin de arttığı tespit edilmiştir. Elde edilen sonuçlar, küçük çocukların daha az akıl yürütme becerisine sahip oldukları ve gerekçelerinin öncüllerle ilgisi olmayan bağlam dışı bilgilere dayalı olduğu şeklinde yorumlanmıştır. Bu da küçük yaştaki çocukların mantıksal ve mantık dışı sonuçlar arasındaki farkları yorumlamak için gerekli akıl yürütme becerisine sahip olmadıkları durumuna kanıt oluşturmuştur (Markovits ve diğ., 1989). Moshman ve Franks (1986) ise çocukların çıkarım mantığını kavramadan önce çoklu aşamalardan geçtiğini belirtmektedir. İlk aşamayı okul öncesi dönemde çocukların mantığın gerekliliğini anlamaksızın mantıksal normlara göre davrandıkları şeklinde tanımlamışlardır (Moshman \& Franks, 1986). İkinci aşama 6 yaş civarında gelişmekte olup çocuk mantığını kullanarak, doğru varsayımlara dayalı olarak sonuçlara ulaşabilmektedir. Son aşamada ise birtakım argümanlarla sonucu destekleyerek bir ifadenin geçerliliğini belirtebilmektedir. Moshman ve Franks yapmış oldukları uygulamalar sonucu son aşamanın 9-10 yaş civarında gelişmeye başladığını belirtmişler ve araştırma 
sonuçlarını çıkarımsal akıl yürütmeye dair tam bir kavrayışın 10 yaşına kadar başlamadığı şeklinde yorumlamışlardır. Moshman ve Franks (1986) okul öncesi yıllarında bile çocukların temel düzey akıl yürütme becerilerine sahip olduğunu, ancak yetişkinliğin erken dönemlerine kadar argümanları formüle edebilme becerilerinin yeterince gelişmediğini belirtmişlerdir. Moshman ve Franks (1986) çıkarımsal akıl yürütme becerisinin gelişiminin zaman alacağı konusunda Piaget ile aynı fikirde olsalar da, Piaget'nin tahmin ettiğinden daha erken dönemde bu becerilerin geliştiğini düşünmektedirler.

Bir grup araştırma ise Piaget'nin çıkarımsal akıl yürütme ile ilgili teorisinin aksine 2-3 yaş civarındaki çocukların bile mantıksal akıl yürütebildiklerini ortaya koymaktadır. Örneğin, Hawkins, Pea, Glick ve Scribner (1984) problemin karmaşıklığının ve bağlamının okul öncesi dönemindeki çocukların çıkarım yapma becerilerini nasıl etkilediğini araştırmışlardır. 4-5 yaşlarındaki 40 çocuğa fantastik, gerçek yaşam ve gerçek yaşamın zıttı bağlamlar içeren problemler verilerek öncüllerle ilgili evet/hayır soruları sorulmuştur. Ayrıca çocuklardan verdikleri cevabı gerekçelendirmeleri istenmiştir. Analiz sonucunda çocukların çıkarımsal akıl yürütmeyi kullanarak geçerli sonuçlara ulaşabildikleri görülmüştür. Araştırmacılar bu durumu çocukların 4-5 yaş civarında bile çıkarımsal akıl yürütmenin ilk aşamalarını gerçekleştirebildikleri şeklinde yorumlamışlardır (Hawkins ve diğ., 1984). Okul öncesi dönemden başlayarak farklı yaş gruplarının mantıksal çıkarımda bulunma becerilerini inceleyen diğer araştırma sonuçları da çocukların küçük yaşlardan itibaren çıkarımsal akı1 yürütmeye dayalı uygulamaları gerçekleştirebildiklerini ortaya koymaktadır (Galotti, Komatsu \& Volez, 1997; Richards ve Sanderson, 1999).

Çocuklara erken yaşlardan itibaren kazandırılabilecek en iyi becerinin düşünmeyi öğretmek olduğunu savunan Matthew Lipman 1970’l1 yıllarda Çocuklar İçin Felsefe (philosophy for children $[\mathrm{P} 4 \mathrm{C}]$ ) programı kapsamında çocukların akıl yürütme becerilerini geliştirmeye yönelik hikâyeler hazırlamıştır. "Harry Stottlemester's Discovery" isimli hikâyede 10-11 yaş grubundaki öğrenciler için mantık ilkelerini keşfeden ve yaşantılarına nasıl aktarabileceği üzerinde konuşan karakterler yaratmıştır. "Harry Stottlemester's Discovery" isimli hikâyesini 5. sınıf öğrencileriyle haftada iki kez, 40'ar dakikalık ders saatlerinde 9 hafta boyunca paylaşmış ve üzerinde tartışma olanağı sağlamıştır. Kontrol gruplu deneysel desende yaptığı çalışmasında, deney grubundaki öğrencilerin mantıksal düşünme becerilerindeki gelişim dikkat çekmiştir. 
Alanyazın incelendiğinde, bazı araştırmacıların 10 yaşlarına kadar çocukların formel çıkarımsal akıl yürütme becerisine sahip olamayacakları yönünde görüş bildirdikleri, bazı araştırmacıların ise bilindik bağlamlar içeren basit formdaki mantıksal akıl yürütmelerin okul öncesi dönemindeki çocuklar tarafından bile gerçekleştirilebildiğini ileri sürdükleri görülmektedir. Türkiye'de ise akıl yürütme yöntemlerini kazandırmayı ve mantıksal düşünmeyi geliştirmeyi hedefleyen mantık dersi klasik ve sembolik mantık olarak liseden itibaren okutulmaya başlanmaktadır. Bu da akıl yürütmeyi destekleyecek formel mantık bilgisinin verilmeye başlanma yaşının oldukça geç olduğunu göstermektedir. Bu tespit, erken yaşlardan itibaren öğrencilerin mantıksal düşünme becerilerinin geliştirilmesine yönelik uygulamaların diğer dersler kapsamında öğretim sürecinde yer aldığı yönündeki görüşler doğrultusunda eleştiri alabilir. Ancak lise düzeyinden daha erken yaşlarda mantıksal düşünme becerilerini geliştirmeye yönelik bir dersin olması gerekliliği ile kastedilen durum formel mantık bilgisidir. Çünkü mantık, önermelerin içerikleriyle ilgilenmemektedir. Önermelerin içeriksel yönden doğruluk ve yanlışlığı ile ilgilenmek bir bilgi konusudur ve içeriksel doğruluk taşıyan önermeler elde etmek bilimlerin işidir. Öğretim sürecinde ilgili ders kapsamında önermelerden yola çıkarak ulaşılabilecek sonuçlar üzerinde tartışma ve akıl yürütme öğrencilere kazandırılması hedeflenen bir durumdur. Fakat öncelikle öğrencilerin mantık ilkelerini ve akıl yürütme yöntemlerini diğer disiplinlerden bağımsız ve formel nitelikte öğrenmesi hedeflenmelidir. Bu nedenle ortaöğretim düzeyinde formel mantık bilgisi verilerek başlayan bu sürecin daha erken yaşlara çekilmesi gerektiği düşünülmektedir.

Bu doğrultuda araştırmanın amac1, ilkokulda ve ortaokulda öğrenim görmekte olan öğrencilerin mantıksal düşünme becerilerini yaş ve sınıf düzeyi değişkenlerine bağlı olarak incelemektir. Sınıf düzeyi ve yaş değişkenlerine bağlı olarak öğrencilerin mantıksal düşünme becerilerindeki değişimi incelemek mantık eğitiminin daha erken yaşlarda verilmeye başlanması gerekliliği konusunda eğitimcilere ve araştırmacılara katkı sağlayabilir. Ayrıca alanyazında var olan belli bir disiplinle ilişkili olarak mantıksal düşünme becerilerini ölçmeye yönelik araçlardan (Aksu, Berberoğlu \& Paykoç, 1990; Geban, Aşkar \& Özkan, 1990; Yaman ve Karamustafaoğlu, 2006; Yüzüak, 2012) farklı olarak, genel mantık konularını kapsayan bir ölçme aracının geliştirilmesi öğrencilerin mantıksal düşünmesini destekleyen akıl ilke ve yöntemlerine sahip olma durumlarını incelemek açısından oldukça önemlidir.

$\mathrm{Bu}$ araştırmada, ilkokul ve ortaokul öğrencilerinin mantıksal düşünme becerilerinin, mantık konularının alt boyutlarına (akıl ilkeleri, akıl yürütme yöntemleri, kavram-tanım, 
sınıflandırma-bölme), yaş ve sınıf düzeyi değişkenlerine göre nasıl değiştiğinin incelenmesi amaçlanmıştır. Bu kapsamda şu alt problemlere yanıt aranmıştır:

İlkokul ve ortaokul öğrencilerinin mantıksal düşünme becerileri,

1. Mantık konularının alt boyutlarına (akıl ilkeleri, akıl yürütme yöntemleri, kavramtanım, sınıflandırma-bölme) göre nasıl değişmektedir?

2. Yaş değiş̧kenine göre nasıl değişmektedir?

3. Sınıf düzeyi değişkenine göre nasıl değişmektedir?

\section{Yöntem}

\section{Araştırmanın Deseni}

$\mathrm{Bu}$ araştırma, betimsel araştırma türlerinden tarama deseni kullanılmıştır. Araştırmada amaç var olan durumu ortaya koymak olduğu için bu araştırma deseni tercih edilmiştir. Tarama deseni kullanılan araştırmalarda katılımcıların görüşleri veya diğer özellikleri daha fazla sayıda kişiye ulaşılarak tespit edilmekte ve betimlenmeye çalışılmaktadır (Büyüköztürk, Çakmak, Akgün, Karadeniz ve Demirel, 2012; Fraenkel, Wallen \& Hyun, 2012). Araştırma verileri araştırmacılar tarafından geliştirilen mantık testi ile toplanmıştır.

\section{Örneklem}

Bu çalışmada iki örneklem grubu bulunmaktadır. Pilot çalışmaya ilişkin veriler birinci gruptan, asıl çalışmaya ilişkin veriler ikinci gruptan toplanmıştır. Birinci örneklem grubunu Burdur il merkezinde bulunan ikisi ilkokul, ikisi ortaokul olmak üzere toplam dört okulda öğrenim görmekte olan 495 öğrenci (\%.56 k1z, \%.44 erkek) oluşturmaktadır. İkinci örneklem grubunu birinci gruptaki öğrencilerden farklı olarak, Burdur il merkezindeki ilkokullarda ve ortaokullarda öğrenim görmekte olan 348 öğrenci (\%48 kız, \%52 erkek) oluşturmaktadır.

Her iki örneklem grubu için çalışmaya 3, 4, 5 ve 6. sınıf öğrencilerinin dahil edilmesinin iki nedeni bulunmaktadır. Birinci neden, lise düzeyinde verilmeye başlayan mantık eğitimini kapsayan konulara ilişkin sorularda daha küçük yaş grubundaki öğrencilerin performanslarını incelemektir. İkinci neden ise testte yer alan soruların düzeyinin bu dört sinıf seviyesindeki öğrencileri kapsayacak uygunlukta olmasıdır. $\mathrm{Bu}$ sınıf düzeylerindeki öğrenciler 8-12 yaş aralığında bulunmaktadır.

Birinci ve ikinci örneklem grubunda bulunan öğrencilerin yaş ve sınıf düzeyi değişkenlerine ilişkin betimsel değerleri Tablo 1'de yer almaktadır. Her iki örneklem grubundaki öğrenciler farklı meslek gruplarına, eğitim düzeyine ve gelir seviyesine sahip 
ailelerden gelmektedir. Çalışma grubundaki öğrencilerin seçiminde uygun örnekleme yönteminden yararlanılmıştır.

Tablo 1. Öğrencilerin Demografik Özelliklerine İlişkin Betimsel Değerler

\begin{tabular}{|c|c|c|c|c|c|c|c|}
\hline \multicolumn{2}{|c|}{ Birinci örneklem grubu için; } & \multirow{2}{*}{$\begin{array}{c}\mathrm{f} \\
76\end{array}$} & \multirow{2}{*}{$\frac{\%}{15,3}$} & \multicolumn{2}{|c|}{ İkinci örneklem grubu için; } & \multirow{2}{*}{$\frac{\mathrm{f}}{51}$} & \multirow{2}{*}{$\begin{array}{c}\% \\
14,7\end{array}$} \\
\hline & 8 & & & & 8 & & \\
\hline & 9 & 130 & 26,3 & & 9 & 92 & 26,4 \\
\hline \multirow[t]{4}{*}{ Yaş } & 10 & 97 & 19,6 & Yaş & 10 & 67 & 19,3 \\
\hline & 11 & 117 & 23,7 & & 11 & 98 & 28,2 \\
\hline & 12 & 75 & 15,1 & & 12 & 40 & 11,5 \\
\hline & 3 & 134 & 27 & & 3 & 76 & 21,8 \\
\hline \multirow{3}{*}{$\begin{array}{c}\text { Sinıf } \\
\text { Düzeyi }\end{array}$} & 4 & 132 & 26,7 & Sinıf & 4 & 90 & 25,9 \\
\hline & 5 & 112 & 22,7 & Düzeyi & 5 & 89 & 25,6 \\
\hline & 6 & 117 & 23,6 & & 6 & 93 & 26,7 \\
\hline
\end{tabular}

\section{Veri Toplama Aracı}

Veri toplama aracı olarak araştırmacılar tarafından geliştirilen mantık testi kullanılmıştır. Test geliştirme aşamasında öncelikle alanyazın kapsamlı bir şekilde taranmış (Emiroğlu, 2012; Özlem, 2012) ve ortaöğretim düzeyinde okutulmakta olan mantık dersi öğretim programı ve ders kitapları detaylı olarak incelenmiştir. Mantık alanına ilişkin kaynaklarda, öğretim programında ve lise ders kitaplarında yer alan klasik mantık konularını kapsayan boyutlara karar verilmiştir. Bu boyutlar akıl ilkeleri, akıl yürütme yöntemleri, önerme, çıkarım (kıyas), kavram ve terim, bölme ve sınıflandırma konularından oluşmaktadır. Mantık testinde yer alan sorular bu boyutları kapsayacak şekilde hazırlanmıştır. Taslak testte yer alan 30 sorunun 5'i akıl ilkeleri, 9'u akıl yürütme yöntemleri, önerme ve kıyas, 12'si kavram ve terim, 4'ü bölme ve sınıflandırma konularından oluşmaktadır. Maddelerin ilgili konuya ilişkin mantıksal düşünme becerilerini ölçecek nitelikte olmasına ve örneklemi oluşturan yaş grubuna uygun olmasına dikkat edilmiştir. Hazırlanan test maddeleri her bir sınıf düzeyinden yaklaşık 30'ar öğrenci olmak üzere 120 kişilik bir gruba uygulanmış ve ön pilot çalışma yapılmıştır. Bu süreçte soruların öğrencilerin düzeyine uygunluğu ve anlaşılırlığı tespit edilmeye çalışılmıştır. 
Ön pilot çalışmaya göre yapılan düzeltmelerden sonra uzman görüşü alınmıştır. Uzmanlardan maddelerin anlaşılırlığı, ilgili konuya uygunluğu, teknik açıdan madde yazım kurallarına uygunluğu, öğrencilerin düzeyine uygunluğu ve bilimsel hata içerip içermediği vb. özellikler bakımından değerlendirme yapmaları istenmiştir. Belirtilen özellikler bakımından "uygun”, "uygun ama geliştirilmeli" ve "uygun değil" seçeneklerini işaretlemeleri ve görüşlerini açıklama bölümüne yazmaları istenmiştir. Testte yer alan maddeler 3 konu alanı uzmanı, 2 ölçme-değerlendirme uzmanı ve 3 öğretmen tarafından incelenmiştir. Uzman görüşleri arasındaki uyum/uyumsuzluk kapsam geçerliği için bir kestirim niteliği taşımaktadır (Yurdugül, 2005). Uzman görüşleri alındıktan sonra Lawshe tekniği kullanılarak her bir madde için kapsam geçerlik oranları (KGO) hesaplanmıştır. Uzmanların yarısının ya da yarısından daha fazlasının "uygun” şeklinde görüş bildirmemesi durumunda KGO değeri 0 ya da negatif değerler aldığından (Yurdugül, 2005) 2 madde elenmiştir. Geriye kalan maddelerin ortalamaları kapsam geçerlik indeksini (KGI) vermektedir. KGO'ların minimum değerleri Veneziano ve Hooper (1997) tarafından tablolaştırılmış olup 8 uzman için minimum kapsam geçerlik ölçütü (KGÖ) değeri 0,78 olarak hesaplanmıştır (Yurdugül, 2005). 28 madde üzerinden uzman görüşü alınan her bir kriter için hesaplanan KGİ değerleri 0,78'den yüksek olup bu sonuç testin kapsam geçerliğinin istatistiksel olarak anlamlılığını göstermektedir (KGİ $>$ KGÖ, $\mathrm{p}=0,05)$.

28 maddelik taslak mantık testinde yer alan soruların 5'i akıl ilkeleri, 4'ü sınıflandırma ve bölme, 5'i tanım, 6'sı kavram ve 8'i akıl yürütme yöntemleri konularını içermektedir. Taslak mantık testi 495 öğrenciye uygulanmış ve pilot uygulama gerçekleştirilmiştir. Pilot uygulamadan elde edilen veriler üzerinden madde analizleri gerçekleştirilmiş olup madde güçlüğü, madde ayırıcılığı ve madde toplam korelasyonu hesaplanmıştır. Madde-toplam korelasyonuna göre, taslak mantık testinde yer alan 2 madde ( 3 ve 5 numaralı maddeler) haricindeki maddelerin öğrencileri mantık konusundaki performansları açısından ayırt ettikleri ve geçerliklerinin yüksek olduğu söylenebilir. 3 ve 5 numaralı maddeler madde ayırıcılık katsayıları 0,19 değerinden düşük olduğu için (Atılgan, Kan \& Doğan, 2007) testten çıkarılmıştır. Testin KR-20 iç tutarlılık katsayısı 0,82 bulunmuştur. Ayrıca testten elde edilen madde ortalama puanlarına göre üst ve alt grupta bulunan öğrenciler arasında yapılan karşılaştırmaya göre iki grubun performansları arasında anlamlı farklılık görülmüştür. Yani testte yer alan maddeler ortalama puanı yüksek olan öğrencilerle düşük olan öğrencileri ayırt etmektedir. 
Testin faktör yapısını belirlemek için pilot uygulamadan elde edilen veriler üzerinden açımlayıcı faktör analizi (AFA) yapılmıştır. AFA öncesinde, örneklem büyüklüğünün faktörleşmeye uygunluğunu test etmek amacıyla Kaiser-Meyer-Olkin (KMO) testi uygulanmıştır. Analiz sonucunda KMO değerinin 0,79 olduğu belirlenmiştir. Bu değer örneklem büyüklüğünün faktör analizine uygunluğu açısından orta derecede yeterli olduğu şeklinde yorumlanmaktadır (Tavşancıl, 2005). Ayrıca Bartlett küresellik testi sonuçları incelendiğinde, elde edilen ki-kare değerinin manidar olduğu görülmüştür $\left(X^{2}{ }_{(495)}=1008,6\right.$ $\mathrm{p}<0,01)$. Bu doğrultuda verilerin çok değişkenli normal dağılımdan geldiği kabul edilmiştir. Puanlamanın kategorik olması nedeniyle tetrakorik korelasyon matrisi üzerinden yapılan AFA sonucunda analize temel olarak alınan 26 maddenin dört faktör altında toplandığı saptanmıştır. Maddelerin faktör yük değerleri incelendiğinde 8 maddenin düşük faktör yük değerine sahip olduğu ya da binişik olduğu görülmüş ve bu nedenle testten çıkarılmıştır. Faktör analizi sonucunda mantık testindeki 18 maddenin 4 faktörlü bir yapı gösterdiği bulunmuştur. Birinci faktördeki maddelerin faktör yük değerleri 0,49-0,62; ikinci faktördeki maddelerin faktör yük değerleri 0,48-0,77; üçüncü faktördeki maddelerin faktör yük değerleri 0,53-0,75; dördüncü faktördeki maddelerin faktör yük değerleri 0,38-0,72 aralığında değişmektedir. Birinci faktör toplam varyansın \% 24'ünü, ikinci faktör \%10'unu, üçüncü faktör \% 7'sini, dördüncü faktör \% 7'sini açıklamaktadır. Faktör döndürme sonuçlarında ortaya çıkan dört faktörlü yapının toplam varyansı açıklama oranının $\% 48$ olduğu tespit edilmiştir. Elde edilen faktör döndürme sonuçları ve faktör deseni Tablo 2'de yer almaktadır.

Tablo 2. Mantık Testinin Faktör Deseni

\begin{tabular}{|c|c|c|c|c|}
\hline \multicolumn{5}{|c|}{ Faktörler } \\
\hline Maddeler & $1^{*}$ & $2^{* *}$ & $3^{* * *}$ & $4^{* * * *}$ \\
\hline 1 & & 0,74 & & \\
\hline 2 & & 0,77 & & \\
\hline 3 & & 0,48 & & \\
\hline 4 & 0,50 & & & \\
\hline 6 & 0,62 & & & \\
\hline 7 & 0,54 & & & \\
\hline 8 & 0,54 & & & \\
\hline 9 & 0,62 & & & \\
\hline 10 & 0,49 & & & \\
\hline 16 & 0,41 & & & \\
\hline 13 & & & 0,71 & \\
\hline 15 & & & 0,82 & \\
\hline 17 & & & 0,53 & \\
\hline
\end{tabular}




\begin{tabular}{cc}
\hline 18 & 0,75 \\
\hline 5 & 0,58 \\
\hline 11 & 0,72 \\
\hline 12 & 0,54 \\
\hline 14 & 0,38 \\
\hline
\end{tabular}

*Birinci faktör: Ak1l yürütme yöntemleri

${ }^{* *}$ İkinci faktör: Akıl ilkeleri

***Üçüncü faktör: Sinıflama-bölme

**** Dördüncü faktör: Kavram-tanım

Yapılan faktör analizi sonucunda mantık testinde 18 soru yer almakta olup ortaya çıkan faktör yapısı ve soru örnekleri Tablo 3'te özetlenmiştir.

Tablo 3. AFA Sonucunda Mantık Testinde Ortaya Çıkan Faktör Desenine İlişkin Soru Örnekleri

\begin{tabular}{|c|c|}
\hline Faktörler ve isimleri & Soru Örnekleri \\
\hline $\begin{array}{l}\text { Faktör 1: Ak1l Yürütme } \\
\text { Yöntemleri }\end{array}$ & $\begin{array}{l}\text { 4. Aşağıda verilen bilgilere göre altı çizili ifade sizce kesin doğru mudur? } \\
\text { Doğru seçeneği işaretleyiniz. } \\
\text { Hasan Ankara'ya veya İstanbul'a gittiyse çikolata getirmiştir. } \\
\text { Hasan çikolata getirmiştir. } \\
\text { O halde Hasan Ankara'ya gitmiștir. } \\
\text { a. Doğrudur. } \\
\text { b. Yanlıştır. }\end{array}$ \\
\hline Faktör 2: Ak1l İlkeleri & $\begin{array}{l}\text { 3. Bir torbaya boşken kırmızı ve beyaz renkte düğmeler atılmıştır. Bu } \\
\text { torbadan çekiliş yapıldığında sizce aşağıdaki hangi seçenek doğru } \\
\text { olabilir? } \\
\text { a. Bu torbadan mavi renkte düğmeler çıkabilir. } \\
\text { b. Bu torbadan başka renkte düğmeler çıkabilir. } \\
\text { c. Bu torbadan kırmızı ve beyaz renkte düğmeler çıkabilir. } \\
\text { d. Bu torbadan pembe renkte düğmeler çıkabilir. }\end{array}$ \\
\hline Faktör 3: Sınıflama-Bölme & $\begin{array}{l}\text { 13. Aşağıdaki kavramları gruplandıracak olsanız nasıl ve neye göre } \\
\text { gruplandırırdınız? Lütfen gruplandırın. } \\
\text { Canlı, Taş, Köpek, Ağaç, Masa, Su, Cansız, İnsan }\end{array}$ \\
\hline Faktör 4: Kavram-tanım & $\begin{array}{l}\text { 5. "Kare dört kenarlıdır. O halde bir şeklin kare olması için dört } \\
\text { kenarının olması yeterlidir." tanımları sizce kesin doğru mudur? } \\
\text { a. Kesin doğrudur. } \\
\text { b. Kesin doğru değildir. }\end{array}$ \\
\hline
\end{tabular}

Pilot uygulamadan elde edilen veriler üzerinden yapılan madde analizleri ve AFA sonucunda teste son şekli verildikten sonra testte yer alan maddelerin madde güçlük indeksleri incelenmiştir (Hingorjo \& Jaleel, 2012). Elde edilen değerler ve maddelerin zorluk düzeyleri Tablo 4'te yer almaktadır.

Tablo 4. Mantık Testindeki Maddelerin Madde Güçlük İndeksleri

$\begin{array}{cccc}0 \leq \mathrm{p}<0.3 & 0.3 \leq \mathrm{p} \leq 0.5 & 0.5<\mathrm{p}<0.7 & \mathrm{p} \geq 0.7 \\ \text { Zor soru } & \text { Kismen zor soru } & \text { Kismen kolay soru } & \text { Kolay soru }\end{array}$




\begin{tabular}{|c|c|c|c|c|c|c|c|}
\hline Madde no & $\begin{array}{c}\text { Madde } \\
\text { zorluk } \\
\text { indeksi }\end{array}$ & Madde no & $\begin{array}{c}\text { Madde } \\
\text { zorluk } \\
\text { indeksi }\end{array}$ & Madde no & $\begin{array}{c}\text { Madde } \\
\text { zorluk } \\
\text { indeksi }\end{array}$ & Madde no & $\begin{array}{c}\text { Madde } \\
\text { zorluk } \\
\text { indeksi }\end{array}$ \\
\hline & & 4 & 0,44 & 7 & 0,61 & 1 & 0,90 \\
\hline & & 5 & 0,49 & 8 & 0,56 & 2 & 0,70 \\
\hline & & 6 & 0,44 & 9 & 0,63 & 3 & 0,75 \\
\hline & & 10 & 0,50 & 13 & 0,58 & 18 & 0,78 \\
\hline & & 11 & 0,32 & 14 & 0,54 & & \\
\hline & & 12 & 0,49 & 15 & 0,61 & & \\
\hline & & 16 & 0,43 & & & & \\
\hline & & 17 & 0,34 & & & & \\
\hline
\end{tabular}

Testte yer alan soruların madde güçlük indeksleri incelendiğinde, 8 madde kısmen zor soru kategorisinde yer alırken 6 madde kısmen kolay soru kategorisinde bulunmaktadır. 3 madde ise kolay soru kategorisindedir. Tablo 4'te yer alan değerler ve madde sayıları testte yer alan maddelerin güçlüklerinin genellikle orta düzeyde yer aldığını göstermektedir.

AFA sonucunda ortaya çıkan dört faktörlü yapının uygunluğunu test etmek için doğrulayıcı faktör analizi (DFA) yapılmıştır. İkinci örneklem grubundan elde edilen verilerin DFA'nın sayıltılarını karşılayıp karşılamadığg kontrol edilmiştir. DFA'dan elde edilen modelin geçerliğini değerlendirmek için alanyazında, $X^{2}$ 'nin örneklem büyüklüğüne duyarlı olması nedeniyle, normlaştırılmış ki-kare olarak adlandırılan $\mathrm{X}^{2} /$ sd oranının kullanılması önerilmekte; büyük örneklemlerde bu oranın 3'ün altında olması mükemmel uyumun göstergesi olarak kabul edilmektedir (Kline, 2005). RMSEA ve RMR değerlerinin 0,05'ten küçük veya eşit olması iyi bir uyumu, 0,05 ile 0,08 arasında olması yeterli bir uyumu, 0,08 ile 0,10 arasında olması ise orta düzeyde uyumu göstermektedir. GFI, AGFI ve CFI indekslerinin 0,95'ten daha büyük olması mükemmel uyumun, 0,90 ve üzerinde olması kabul edilebilir bir uyumun göstergesidir (Tabachnick \& Fidell, 2001). DFA sonucunda dört faktörlü modelin kabul edilebilir bir uyum iyiliğine sahip olduğu görülmüştür (Şekil 1), $X^{2}=221,22(s d=129) X^{2} / s d$ = 1,71 RMSEA=0,045; RMR=0,013; GFI=0,93; AGFI=0,91; CFI=0,90. 


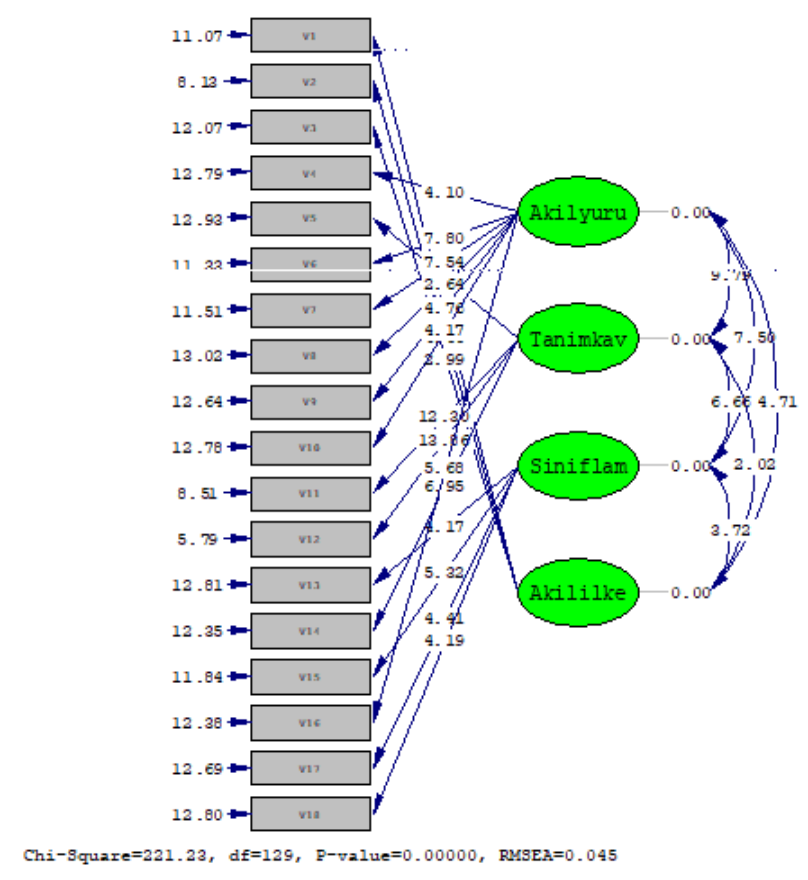

Şekil 1. Mantıksal Düşünme Yeteneği Testi İçin Standardize Edilmiş DFA Sonuçları ve t Değerleri

\section{Veri Toplama Aracının Uygulanması}

Burdur İl Milli Eğitim Müdürlüğü’nden gerekli izinler alındıktan sonra taslak mantık testi ile pilot uygulama gerçekleştirilmiştir. Öğrencilerin test sorularını yanıtlamaları için bir ders saati verilmiştir. Bu süre hem ilkokul hem de ortaokul öğrencilerinin testi tamamlamaları için yeterli olmuştur. Uygulamalar öğretmen eşliğinde araştırmacılar tarafindan yapılmıştır. Uygulama esnasında öğrencilere araştırmacının kimliği, testin içeriği, çalışmanın amacı ve cevaplama süresi konusunda bilgilendirme yapılmıştır. Ayrıca teste ilişkin cevaplarının karne notlarını etkilemeyeceği belirtilmiştir.

\section{Veri Analizi}

Araştırmanın pilot uygulaması ile elde edilen verilerin çözümlenmesinde sorulara doğru yanıt verenlere 1 puan, yanlış yanıt verenlere ve soruyu boş bırakanlara 0 puan verilmiştir. Pilot uygulama ile elde edilen veriler doğru-1 ve yanlış/boş-0 olarak kodlandıktan sonra, maddelerin madde ayırıcılık katsayıları ve madde güçlük indeksleri hesaplanmıştır. Ayrıca mantık testinde yer alan her bir sorunun üst grupta bulunan yani soruyu bilen öğrenciler ile alt grupta bulunan öğrencileri ayırt etme durumu hesaplanmıştır. Pilot uygulamadan elde edilen verilerin 
puanlamasının kategorik olması sebebiyle tetrakorik korelasyon matrisi üzerinden açımlayıcı faktör analizi yapılmıştır. Verilerin faktör analizine uygunluğu Kaiser-Meyer-Olkin (KMO) katsayısı ve Barlett testi ile kontrol edilmiştir. Faktörleştirme tekniği olarak temel bileşenler analizi ve varimax dik döndürme tekniği kullanılmıştır. Analizde maddelerin faktör yükleri ve varyans oranları incelenmiştir. Asıl uygulamadan elde edilen veriler doğru-1 ve yanlış/boş-0 olarak kodlandıktan sonra doğrulayıcı faktör analizi uygulanmıştır.

Asıl uygulamadan elde edilen veriler SPSS programı kullanılarak analiz edilmiştir. Öncelikle verilerin normallik varsayımını karşılayıp karşılamadığını test etmek için Kolmogorov-Smirnov testi uygulanmış ve verilerin normal dağılım göstermediği $(\mathrm{p}<.05)$ sonucuna ulaşılması sebebiyle parametrik olmayan testler tercih edilmiştir. Birinci araştırma sorusuna yanıt aramak için öğrencilerin mantık konularının alt boyutlarındaki performanslarına yönelik betimsel istatistiklere yer verilmiştir. Yaş ve sınıf düzeyi değişkenlerine ilişkin değişimi incelemek için Kruskal Wallis testi kullanılmış olup fark çıkması durumunda farkın hangi grup lehine oluştuğunu belirlemek amacıyla Mann Whitney U testi kullanılmıştır. İstatistiksel analizler için anlamlılık seviyesi 0.05 olarak kararlaştırılmıştır.

\section{Bulgular}

\section{Birinci Alt Probleme İlişkin Bulgular}

İlkokul ve ortaokul öğrencilerinin mantıksal düşünme becerilerinin mantık testinde yer alan alt boyutlara göre nasıl değiştiğini incelemek amacıyla öğrencilerin doğru ve yanlış yanıtlarına ilişkin betimsel değerlere (Tablo 5) yer verilmiştir.

Tablo 5. Mantık Testindeki Alt Boyutlara İlişkin Doğru ve Yanlış Yanıtların Dağılımı

\begin{tabular}{|c|c|c|c|c|c|c|c|}
\hline \multirow{2}{*}{$\begin{array}{l}\text { Mantık testi alt } \\
\text { boyutları }\end{array}$} & \multirow[b]{2}{*}{ Madde no } & \multicolumn{2}{|c|}{ Doğru } & \multicolumn{4}{|c|}{ Yanlış } \\
\hline & & Frekans & Yüzde & $\begin{array}{l}\text { Ortalama } \\
(\%)\end{array}$ & Frekans & Yüzde & $\begin{array}{c}\text { Ortalama } \\
(\%)\end{array}$ \\
\hline \multirow{7}{*}{ 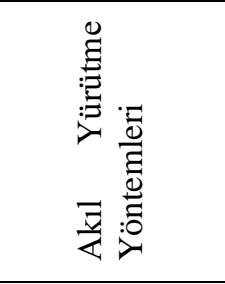 } & 4 & 142 & 40,8 & \multirow{7}{*}{55,5} & 206 & 59,2 & \multirow{7}{*}{44,5} \\
\hline & 6 & 154 & 44,3 & & 194 & 55,7 & \\
\hline & 7 & 199 & 57,2 & & 149 & 42,8 & \\
\hline & 8 & 224 & 64,4 & & 124 & 35,6 & \\
\hline & 9 & 229 & 65,8 & & 119 & 34,2 & \\
\hline & 10 & 204 & 58,6 & & 144 & 41,4 & \\
\hline & 16 & 200 & 57,5 & & 148 & 42,5 & \\
\hline \multirow{3}{*}{ 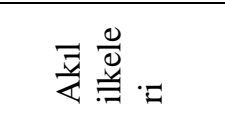 } & 1 & 298 & 85,6 & \multirow{3}{*}{75,4} & 50 & 14,4 & \multirow{3}{*}{24,6} \\
\hline & 2 & 217 & 62,4 & & 131 & 37,6 & \\
\hline & 3 & 272 & 78,2 & & 76 & 21,8 & \\
\hline \multirow{4}{*}{ 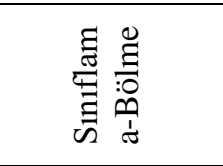 } & 13 & 211 & 60,6 & \multirow{4}{*}{64,4} & 137 & 39,4 & \multirow{4}{*}{35,6} \\
\hline & 15 & 241 & 69,3 & & 107 & 30,7 & \\
\hline & 17 & 154 & 44,3 & & 194 & 55,7 & \\
\hline & 18 & 291 & 83,6 & & 57 & 16,4 & \\
\hline \multirow{3}{*}{ 茎完志 } & 5 & 173 & 49,7 & \multirow{3}{*}{45,1} & 175 & 50,3 & \multirow{3}{*}{55,8} \\
\hline & 11 & 124 & 35,6 & & 224 & 64,4 & \\
\hline & 12 & 170 & 48,9 & & 178 & 51,1 & \\
\hline
\end{tabular}


Tablo 5'te yer alan veriler incelendiğinde, öğrencilerin en yükssek ortalamaya çelişmezlik ve üçüncü halin imkânsızlığını içeren akıl ilkeleri boyutunda ulaştıkları görülmüştür. Üçüncü halin imkânsızlığını ölçen 1 numaralı soruda öğrencilere bir kapının aralık olması durumunda açık mı yoksa kapalı mı olduğu sorulmuş ve gerekçelerini yazmaları istenmiştir. Öğrencilerin \% 86'sı bu soruya “açık" diyerek doğru yanıt vermiştir. "Kapalı" yanıtını veren öğrencilerin gerekçeleri incelendiğinde, şu yanıtları verdikleri görülmektedir:

“Bir kapı tam açılmadı̆̆ı zaman açık sayılmaz.” (HÇ)

“Çünkü aralıksa açık değildir.” (MÇ)

“Çünkü kapı az aralık da olsa kapalıdır.” (CE)

“Çünkü azıcık aralık olduğu için kapalı da sayılır." (SY)

Bu soruda bir öğrenci her iki yanıtın da doğru olmayacağını belirterek gerekçesini “íkisi de değildir. Çünkü kapı açıkken kapatılmak istenmiştir ama kapanmamıştır ve ikisinin arasında kalmıştır. Bu durumda kapı açık ve kapalı olma görevlerini yerine getirmez.” şeklinde açıklamıştır.

Üçüncü halin imkânsızlığı ilkesini ölçmeye yönelik bir diğer soru 3 numaralı sorudur. Bu soruda öğrencilere boş bir torbaya kırmızı ve beyaz renkte düğmeler atıldıktan sonra çekiliş yapıldığında seçeneklerdeki hangi durumun doğru olacağı sorulmuştur. Öğrencilerin \% 78'i “Torbadan kırmızı ve beyaz renkte düğmeler çıkabilir." seçeneğini işaretlerken \% 22'si torbadan mavi renkte, pembe renkte ve başka renkte düğmeler çıkabileceğine yönelik seçenekleri işaretlemişlerdir. Bu durum öğrencilerin bir kısmının belirtilen bağlamda üçüncü halin imkânsızlığı ilkesini kullanamadıklarını göstermektedir. Akıl ilkeleri boyutundaki bir diğer soru çelişmezlik ilkesini ölçmeye yönelik hazırlanan 2 numaralı sorudur. Bu soruda öğrencilere hırsızlık suçu ile suçlanan bir kişinin hırsızlığın yapıldığı zaman orada olmadığını ispat etmesi durumunda hâkimin ne karar vereceği sorulmuştur. Öğrencilerin \% 62'si kişiyi suçsuz bulacağını belirterek gerekçesini genellikle kişinin orada olmadığını ispat etmesiyle açıklamışlardır. Öğrencilerin \% 38'i ise bu soruya yanlış yanıt vermiştir. Bu öğrencilerden bazılarının gerekçelerini şu şekilde ifade ettikleri görülmüştür:

“Çünkü hırsızlar güvenilir kişiler değillerdir.” (YT)

“Bence hakimlerin karar vermesi gerekir. Çünkü doğru ya da yanlış olanı onlar belirler.” (KU)

"İspat edebilir ama yalan söyleme ihtimali var." (UY) 
Öğrencilerin gerekçeleri incelendiğinde, doğru yanıt veren öğrenciler hırsızlık anında orada olmayan birisinin hırsızlık ile suçlanamayacağı görüşünde iken yanlış yanıt veren öğrenciler olayı öznel boyutta değerlendirmiş, hırsızların doğru söylemeyeceği ve bu duruma hakimlerin karar verebileceği yönünde görüş bildirmişlerdir. Öğrencilerin doğru yanıt verme oranı açısından ikinci sırada yer alan boyut sınıflama-bölme' dir. Sınıflama-bölme sorularından ikisi (13 ve 15 numaralı sorular) canlı-cansız varlıklar, erkek isimleri-kız isimleri ya da ismi A harfi ile başlayanlar-ismi H harfi ile başlayanlar şeklinde sınıflama yapmayı gerektirmektedir. Öğrencilerin bu iki sorudaki doğru yanıt oranı \% 60-70 aralığında değişmektedir. Bu durum öğrencilerin yaklaşık \% 40'nın basit düzeyde sınıflama gerektiren soruları yapamadığını göstermektedir. 17 numaralı soruda öğrencilere kış, yaz, sonbahar ve ilkbahar mevsimlerinin her birinin üçer aydan oluştuğu ve bunların bir yılın mevsimleri olduğu durumları belirtilerek “O halde bütün mevsimler ............." ifadesindeki boşluğu doldurmaları istenmiştir. $\mathrm{Bu}$ soru sınıflama-bölme boyutunda yazılmamasına rağmen faktör analizi sonucunda bu boyutta tanımlanmıştır. $\mathrm{Bu}$ durumun nedeni, 12 ayın üçer aylık zaman dilimleri olarak sınıflandırılmasına yönelik bağlamla açıklanabilir. Bu soruda öğrencilerin \% 56'sı belirtilen boşluğa uygun ifadeyi (üçer aydır) yazamamıştır.

Sınıflandırma boyutundaki 18 numaralı soruda "İnsan mavi gözlü bir canlıdır." şeklindeki bir ifadenin insanı tanımlamak için yeterli olup olmadığı sorulmuştur. Bu soru tanım boyutunda hazırlanmış olup faktör analizi sonucunda sınıflandırma boyutunda yer almıştır. $\mathrm{Bu}$ durum insan için yapılan tanımlamanın göz renklerini dikkate alarak yapılan bir sınıflamayı içerip içermemesi durumunu ölçmesinden kaynaklanabilir. Ayrıca mantık alanyazınında sınıflandırma konusunun tanım ve kavram konularıyla içiçe geçmesi bu durumu açıklamaktadır. Bu soruya öğrencilerin \% 84'ü doğru yanıt vermiştir. Ancak öğrencilerin \% 16's1 insanı mavi gözlü bir canlı olarak tanımlamanın yeterli olacağını düşünmektedir. Bu öğrencilerin insanın mavi gözlü canlı olarak tanımlanmasının bütün insanları kapsamaması sebebiyle yeterli olmayacağını kestiremediği görülmektedir. Bu da mantık alanında eksik sınıflandırma olarak ifade edilen durumun gerçekleştiğini göstermektedir. Sınıflandırma yaparken öyle özellikler seçmek gerekir ki bu özellikler birbirine bağlanabilmeli ve konuların ya da nesnelerin tümünde ortak olmalıdır (Özlem, 2012). Örneğin hayvanları göz renklerine göre değil de omurgalı/omurgasız diye ayırmak mantıksal yoldan ortak olan birincil özelliklerin yani başat karakterlerin dikkate alındığını gösterir (Özlem, 2012). Bu durumda, soruya doğru yanıt veremeyen \% 14 oranındaki öğrenci grubunun insanı tanımlamada birincil özelliklerin kullanılması gerektiği düşüncesine sahip olmadığı görülmektedir. 
Öğrencilerin ortalama \% 55,5 doğru yanıt verme oranıyla üçüncü sırada yer alan boyut akıl yürütme yöntemleri boyutudur. Ak1l yürütme yöntemleri boyutunda 7 soru yer almaktadır. Öğrencilerin sorulara verdikleri yanıtların doğruluk oranları \%40- \%66 aralığında değişmektedir. Akıl yürütme için, bir kanıtlayan (öncül) ve bir de kanıtlanan (sonuç) durumunda en az iki önermenin bulunması gerekmekte olup bu boyutta yer alan sorularda öncüller verilip öğrencilerden sonuç çıkarmaları ya da çıkarılan sonuçların doğruluğunu belirlemeleri istenmektedir. Öğrencilerin bu boyuttaki sorular içerisinde en düşük performansı 4 numaralı soruda gösterdikleri görülmüştür. Bu soruda öğrencilere "Hasan Ankara'ya veya İstanbul'a gittiyse çikolata getirmiştir.", "Hasan çikolata getirmiştir.” öncülleri verilerek "O halde Hasan Ankara’ya gitmiştir.” sonucunun kesin doğru olup olmadığı hakkında karar vermeleri istenmiştir. Öğrencilerin diğer sorulara göre daha düşük performans göstermeleri birinci öncülde "veya" ifadesinin yer alması ve sonucun kesin doğruluğunun sorulması ile açıklanabilir. Öğrencilerin bir kısmı sonucun kesinliğine dikkat etmeksizin Hasan'ın çikolata getirmesi durumunda Ankara'ya gittiğini düşünmüştür.

Öğrenciler en düşük performansı kavram-tanım sorularında göstermiş olup sorulara doğru yanıt verme oranı \%36-\%50 aralığında değişmektedir. Öğrenciler bu boyuttaki en düşük performansı 11 numaralı soruda göstermiştir. Bu soruda öğrencilere hangi durumun deney ve gözleme başvurmadan bilinebileceği sorulmuş ve öğrencilerden "Bütün parçalarından büyüktür." yanıtını vermeleri beklenmiştir. Bu sorunun tanım-kavram boyutunda yer almasının sebebi öğrencilerin bütün ve parça kavramlarına ilişkin tanımlama yapıp yapamadıklarını değerlendirmektir. Ancak öğrencilerin çoğunluğu bu soruda uygun seçeneği işaretleyememiştir. Fakat parça-bütün kavramlarını ve kavramlar arasındaki ilişkiyi değerlendirmeyi gerektiren benzer nitelikteki 14 numaralı soruda doğru yanıt oranı \% 46' dır. Bu durumun sebebi 14 numaralı soruda parça-bütün ilişkisinin elma örneği üzerinden verilmesi ile açıklanabilir. Soruda bir elmanın ikiye bölünmesi durumunda parçalardan birisinin bütünden küçük olacağını bilmeleri beklenmektedir. Her ne kadar parça-bütün ilişkisini bağlam üzerinden değerlendirmeyen 11 numaralı soruya göre bağlam eklendiğinde öğrencilerin doğru yapma oranı artsa da bir elmanın ikiye bölündüğünde parçalardan birisinin bütünden küçük olacağını belirten öğrenci oranı \% 46'dır. Oysaki matematik dersi öğretim programları incelendiğinde 1. sınıftan itibaren kademeli olarak bütün-yarım, bütün-yarımçeyrek ve parça-bütün kavramları ve bu kavramlar arasındaki ilişkiler kesirler alt öğrenme alanı içerisinde vurgulanan konulardır.

\section{İkinci Alt Probleme İlişkin Bulgular}


İlkokul ve ortaokul öğrencilerinin mantık testindeki performanslarının yaş değişkenine göre nasıl değiştiğini incelemek için Kruskal Wallis H-testi uygulanmıştır. Analiz sonucunda elde edilen veriler Tablo 6'da yer almaktadir.

Tablo 6. Öğrencilerin Mantık Testindeki Performanslarının Yaş Değişkenine Göre Değişimine İlişkin Kruskal Wallis H-Testi Sonuçları

\begin{tabular}{ccccccc}
\hline Yaş & N & Sira Ort. & sd & $\mathrm{X}^{2}$ & $\mathrm{p}$ & Anlamlı Fark \\
\hline 8 & 51 & 149,59 & & & & \\
\hline 9 & 92 & 158,99 & & & & \\
\hline 10 & 67 & 175,08 & & 10,577 & .032 & $8-11,8-12,9-11$ \\
\hline 11 & 98 & 191,84 & & & & \\
\hline 12 & 40 & 198,48 & & & & \\
\hline
\end{tabular}

Tablo 6'da yer alan verilere göre, öğrencilerin mantıksal düşünme becerileri yaşa bağlı olarak artmaktadır. Öğrencilerin mantık testindeki performansları özellikle 8-11, 8-12 ve 9-11 yaş grupları arasında anlamlı bir şekilde farklılaşmaktadır. Bu durum 11-12 yaşlarındaki öğrencilerin mantıksal düşünme becerisinin 8-9 yaşlarındaki öğrencilere göre anlamlı bir farkla daha yüksek olduğunu göstermektedir.

\section{Üçüncü Alt Probleme İlişkin Bulgular}

Öğrencilerin sorulara verdikleri doğru ve yanlış yanıt oranları sınıf düzeylerine bağlı olarak incelenmiş ve oranlara ilişkin betimsel analizlere Tablo 7'de yer verilmiştir. Tabloda yer alan veriler incelendiğinde, özellikle 3. ve 4. sınıf öğrencilerinin kavram-tanım boyutunda yer alan 5, 11, 12 ve 14 numaralı sorularda daha düşük performans gösterdiği görülmektedir. Bu boyuttaki sorular kavramları, tanımlarını ve kavramların birbirleriyle ilişkisini kavramayı gerektirmektedir. Örneğin 5 numaralı soruda "Kare dört kenarlıdır. O halde bir şeklin kare olması için dört kenarının olması yeterlidir." tanımlarının kesin doğru olup olmadığı sorulmuştur. Bu soruya 3. ve 4. sınıf öğrencileri \%35 civarında doğru cevap verirken 5. sınıf öğrencileri \% 50, 6. sınıf öğrencileri \% 70 civarında doğru yanıt vermiştir. Matematik Dersi Öğretim Programı (2018) incelendiğinde, birinci sınıftan itibaren öğrenciler dört kenarlı şekiller üzerinde çalışmakta ve birtakım materyalleri kullanarak kare, dikdörtgen gibi geometrik şekilleri modellemektedir. Dolayısıyla bu soruda 3. ve 4. sınıf öğrencilerinin her dört kenarlı şekle kare denilemeyeceği çıkarımını yapabilmesi beklenmektedir. Bunun yanında, 3. ve 4. sınıf öğrencilerinin bazı sorularda (örneğin, 1, 3, 17, 18 numaralı sorular) ortaokul öğrencilerinin geneliyle, bazı sorularda (örneğin, 6, 8, 10,16, 18 numaralı sorular) ise sadece 5. sınıf öğrencileriyle birbirine yakın performans gösterdiği görülmektedir. $\mathrm{Bu}$ 
durumda soruların ilişkili oldukları konuya, zorluk derecesine, bağlamına ve yapısına bağlı olarak öğrencilerin mantıksal düşünme becerilerinin farklılaştığı söylenebilir.

Tablo 7. Sınıf Düzeyi Bazında Sorulara Doğru Yanıt Verilme Oranları

\begin{tabular}{|c|c|c|c|c|c|c|c|}
\hline Madde no & $\begin{array}{c}\text { Sinıf } \\
\text { Düzeyi }\end{array}$ & $\begin{array}{c}\text { Doğru } \\
(\%)\end{array}$ & $\begin{array}{c}\text { Yanlış } \\
(\%)\end{array}$ & Madde no & $\begin{array}{c}\text { Sinıf } \\
\text { Düzeyi }\end{array}$ & Doğru & Yanlış \\
\hline \multirow{4}{*}{1} & 3 & $\% 90,8$ & $\% 9,2$ & \multirow{4}{*}{10} & 3 & $\% 48,7$ & $\% 51,3$ \\
\hline & 4 & $\% 82,2$ & $\% 17,8$ & & 4 & $\% 58,9$ & $\% 41,1$ \\
\hline & 5 & \%82 & $\% 18$ & & 5 & $\% 52,8$ & $\% 47,2$ \\
\hline & 6 & $\% 88,2$ & $\% 11,8$ & & 6 & $\% 72$ & $\% 28$ \\
\hline \multirow{4}{*}{2} & 3 & $\% 42,1$ & $\% 57,9$ & \multirow{4}{*}{11} & 3 & $\% 22,4$ & $\% 77,6$ \\
\hline & 4 & $\% 56,7$ & $\% 43,3$ & & 4 & $\% 30$ & $\% 70$ \\
\hline & 5 & $\% 68,5$ & $\% 31,5$ & & 5 & $\% 37,1$ & $\% 62,9$ \\
\hline & 6 & $\% 78,5$ & $\% 21,5$ & & 6 & $\% 50,5$ & $\% 49,5$ \\
\hline \multirow{4}{*}{3} & 3 & $\% 72,4$ & $\% 27,6$ & \multirow{4}{*}{12} & 3 & $\% 38,2$ & $\% 61,8$ \\
\hline & 4 & $\% 77,8$ & $\% 22,2$ & & 4 & $\% 37,8$ & $\% 62,2$ \\
\hline & 5 & $\% 78,7$ & $\% 21,3$ & & 5 & $\% 50,6$ & $\% 49,4$ \\
\hline & 6 & $\% 82,8$ & $\% 17,2$ & & 6 & $\% 66,7$ & $\% 33,3$ \\
\hline \multirow{4}{*}{4} & 3 & $\% 34,2$ & $\% 65,8$ & \multirow{4}{*}{13} & 3 & $\% 42,1$ & $\% 57,9$ \\
\hline & 4 & $\% 26,7$ & \%73,3 & & 4 & $\% 57,8$ & $\% 42,2$ \\
\hline & 5 & $\% 43,8$ & $\% 56,2$ & & 5 & $\% 70,8$ & $\% 29,2$ \\
\hline & 6 & $\% 57$ & $\% 43$ & & 6 & $\% 68,8$ & $\% 31,2$ \\
\hline \multirow{4}{*}{5} & 3 & $\% 31,6$ & $\% 68,4$ & \multirow{4}{*}{14} & 3 & $\% 25$ & $\% 75$ \\
\hline & 4 & $\% 38,9$ & $\% 61,1$ & & 4 & $\% 48,9$ & $\% 51,1$ \\
\hline & 5 & $\% 53,9$ & $\% 46,1$ & & 5 & $\% 48,3$ & $\% 51,7$ \\
\hline & 6 & $\% 71$ & $\% 29$ & & 6 & $\% 59,1$ & $\% 40,9$ \\
\hline \multirow{4}{*}{6} & 3 & $\% 34,2$ & $\% 65,8$ & \multirow{4}{*}{15} & 3 & $\% 55,3$ & $\% 44,7$ \\
\hline & 4 & $\% 37,8$ & $\% 62,2$ & & 4 & $\% 66,7$ & $\% 33,3$ \\
\hline & 5 & $\% 38,2$ & $\% 61,8$ & & 5 & $\% 73$ & $\% 27$ \\
\hline & 6 & $\% 64,5$ & $\% 35,5$ & & 6 & $\% 79,6$ & $\% 20,4$ \\
\hline \multirow{4}{*}{7} & 3 & $\% 51,3$ & $\% 48,7$ & \multirow{4}{*}{16} & 3 & \%56,6 & $\% 43,4$ \\
\hline & 4 & $\% 46,7$ & $\% 53,3$ & & 4 & $\% 44,4$ & $\% 55,6$ \\
\hline & 5 & $\% 56,2$ & $\% 43,8$ & & 5 & $\% 55,1$ & $\% 44,9$ \\
\hline & 6 & $\% 73,1$ & $\% 26,9$ & & 6 & $\% 73,1$ & $\% 26,9$ \\
\hline \multirow{4}{*}{8} & 3 & $\% 61,8$ & \%38,2 & \multirow{4}{*}{17} & 3 & $\% 40,8$ & $\% 59,2$ \\
\hline & 4 & $\% 55,6$ & $\% 44,4$ & & 4 & $\% 43,3$ & $\% 56,7$ \\
\hline & 5 & $\% 56,2$ & $\% 43,8$ & & 5 & $\% 42,7$ & $\% 57,3$ \\
\hline & 6 & $\% 82,8$ & $\% 17,2$ & & 6 & $\% 49,5$ & $\% 50,5$ \\
\hline
\end{tabular}




\begin{tabular}{|c|c|c|c|c|c|c|c|}
\hline \multirow{4}{*}{9} & 3 & $\% 50$ & $\% 50$ & \multirow{4}{*}{18} & 3 & $\% 84,2$ & $\% 15,8$ \\
\hline & 4 & \%63,3 & $\% 36,7$ & & 4 & \%80 & $\% 20$ \\
\hline & 5 & $\% 70,8$ & $\% 29,2$ & & 5 & \%82 & \%18 \\
\hline & 6 & \%76,3 & $\% 23,7$ & & 6 & $\% 88,2$ & $\% 11,8$ \\
\hline
\end{tabular}

Öğrencilerin mantık testindeki performanslarının sınıf düzeyine bağlı olarak nasıl değiştiğini incelemek için Kruskal Wallis H-testi uygulanmış olup test sonuçları Tablo 8'de verilmiştir.

Tablo 8. Öğrencilerin Mantık Testindeki Performanslarının Sınıf Düzeyi Değişkenine Göre Değişimine İlişkin Kruskal Wallis H-Testi Sonuçları

\begin{tabular}{|c|c|c|c|c|c|c|}
\hline Sınıf düzeyleri & $\mathrm{N}$ & Sira Ort. & sd & $\mathrm{X}^{2}$ & $\mathrm{p}$ & Anlamlı Fark \\
\hline 3. sinif & 76 & 121,49 & \multirow{4}{*}{3} & \multirow{4}{*}{65,04} & \multirow{4}{*}{.000} & \multirow{4}{*}{$3-5,3-6,4-5,4-6,5-6$} \\
\hline 4. sinif & 90 & 147,52 & & & & \\
\hline 5. sinif & 89 & 181,10 & & & & \\
\hline 6.sinif & 93 & 237,61 & & & & \\
\hline
\end{tabular}

Tablo 8'de yer alan verilere göre, ilkokul ve ortaokul öğrencilerinin mantık testindeki performanslarının sınıf düzeylerine bağlı olarak anlamlı bir şekilde farklılaştığı tespit edilmiş̧ir, $\mathrm{X}^{2}(\mathrm{sd}=3, \mathrm{n}=348)=65,04, \mathrm{p}<.05$. Grupların sıra ortalamaları dikkate alındığında, sınıf düzeyi arttıkça öğrencilerin mantıksal düşünme becerilerinin arttığı görülmektedir. Bu artışın hangi sınıf düzeylerinde anlamlı olduğunu test etmek için yapılan Mann Whitney U testi sonucunda 3-5, 3-6, 4-5, 4-6 ve 5-6 sınıf düzeyleri arasında anlamlı farka rastlanmıştır. Bu durum 5. ve 6. sinıftaki öğrencilerin mantıksal düşünme becerilerinin 3. ve 4. sinıftaki öğrencilere göre anlamlı bir şekilde daha yüksek olduğunu ortaya koymaktadır. Sıra ortalamalarına göre 6. sınıf öğrencilerinin performansının 5. sınıflardan oldukça yüksek olduğu görülmektedir. $\mathrm{Bu}$ durum 6. sinıftaki öğrencilerin 11-12 yaş aralığında olması sebebiyle öğrencilerin çoğunluğunun soyut işlemler dönemine geçmiş olmasıyla açıklanabilir.

\section{Tartışma, Sonuç ve Öneriler}

$\mathrm{Bu}$ araştırmada 8-12 yaş aralığındaki öğrencilerin mantıksal düşünme becerilerini ölçmeye yönelik test geliştirilmesi ve öğrencilerin yaş ve sınıf düzeyi değişkenlerine bağlı olarak mantık testindeki performanslarının nasıl değiştiğinin incelenmesi amaçlanmıştır. Bunun için öncelikle klasik mantık konularını içeren akıl ilkeleri, akı1 yürütme yöntemleri, önerme, kıyas, sınıflandırma, bölme, tanım ve kavram konularını kapsayan sorular hazırlanmış 
ve geçerlik ve güvenirlik çalışmaları yapılmıştır. Elde edilen sonuçlar 8-12 yaş aralığındaki öğrencilerin mantıksal düşünme becerilerini ölçmek için hazırlanan ölçme aracının akıl ilkeleri, akıl yürütme yöntemleri, sınıflandırma-bölme ve tanım-kavram boyutlarından oluştuğunu ve mantık testinin geçerli ve güvenilir olduğunu ortaya koymaktadır. Alanayazında öğrencilerin mantıksal düşünme becerilerini ölçmeye yönelik çalışmalar incelendiğinde bazı ölçme araçlarının Türkçeye uyarlanarak literatüre kazandırıldığg görülmektedir (Aksu, Berberoğlu \& Paykoç, 1990; Geban, Aşkar \& Özkan, 1990; Haciömeroğlu \& Haciömeroğlu, 2018; Yaman ve Karamustafaoğlu, 2006; Yüzüak, 2012). Bu ölçme araçları incelendiğinde genellikle fen ve matematik alanlarını içeren sorulardan oluştuğu görülmüştür (Aksu, Berberoğlu \& Paykoç, 1990; Geban, Aşkar \& Özkan, 1990; Hacıömeroğlu \& Hacıömeroğlu, 2018; Yaman ve Karamustafaoğlu, 2006; Yüzüak, 2012). Bu araştırma kapsamında geliştirilen mantıksal düşünme yeteneği testinde, Mantık Dersi Öğretim Programı (2009)'nın ve mantık konularının içeriğine yer verilmiş olup diğer disiplinlerden bağımsız olarak öğrencilerin akıl yürütme becerilerinin incelenmesi hedeflenmiştir. Elde edilen bulgular sonucunda, salt ve formel mantık bilgisini ölçmeye yönelik bir test olması özelliğiyle, 8-12 yaş grubundaki öğrencilerin mantıksal düşünme becerilerini ölçebilecek nitelikte geçerli ve güvenilir bir araç olduğu söylenebilir.

Mantık ilkeleri olarak da isimlendirilen akıl ilkeleri mantığın üç ana ilkesi olarak görülmektedir. Mantık, kavram, önerme ve çıkarımlarla ilgili kurallar, teknikler ve yöntemler öğretisi olarak tanımlanmakta olup tüm bu kuralların, tekniklerin ve yöntemlerin üç ilkeden hareketle geliştirildiğini belirtmektedir. Çoğu mantıkçı mantığa bu üç ilkeye dayalı sistem gözüyle bakmaktadır (Özlem, 2012). Özdeşlik, çelişmezlik ve üçüncü halin imkânsızlığı durumlarından oluşan akıl ilkeleri aslında mantığın temelini oluşturan akıl yürütmede önerme kurmanın ve çıkarım yapmanın vazgeçilmez dayanakları olarak görülmektedir (Özlem, 2012). Mantığın temelini oluşturan akıl ilkeleri boyutunun en yüksek doğru yanıt oranına sahip olması 8-12 yaş aralığındaki çocukların büyük bir kısmının mantıksal düşünmeye dayanak oluşturan temel ilkeleri kullanabildiklerini göstermektedir. Mantıksal düşünme becerisini incelemeye yönelik hazırlanan ve Türkçe'ye uyarlaması yapılan testler incelendiğinde, testlerde yer alan soruların bilişsel gelişim dönemlerinin (somut operasyonel, geçiş dönemi ve formal operasyonel) özelliklerini yansıtan boyutlarda toplandığı görülmektedir (Aksu, Berberoğlu \& Paykoç, 1990; Haciömeroğlu \& Haciömeroğlu, 2018). Örneğin, Kıncal ve Yazgan (2010) tarafından yapılan çalışmada Aksu, Berberoğlu ve Paykoç (1990) tarafindan Türkçeye uyarlanan Mantıksal Düşünme Grup Testi kullanılmış ve ortaokul 7. ve 8. sınıf öğrencilerinin 
mantıksal düşünme becerileri bilişsel gelişim dönemlerine göre incelenmiştir. Araştırma sonucunda öğrencilerin 11 yaşından büyük olmalarına rağmen mantıksal düşünme becerilerinin somut işlemler dönemine uygun olduğu bulgusuna ulaşılmış ve bu sonuç öğrencilerin soyut işlemler döneme daha ileriki yaşlarda ulaşacağ ş̧eklinde yorumlanmıştır (Kıncal \& Yazgan, 2010). Bu araştırma sonucunda somut işlemler döneminde olan 8-9 yaşlarındaki öğrencilerin mantıksal düşünme becerilerinin gelişimi 11-12 yaşlarındaki öğrencilerden anlamlı bir şekilde daha düşük çıkmıştır. Ancak soruların özelliklerine bağlı olarak 8-9 yaşlarındaki öğrencilerin mantıksal düşünme becerilerinin daha büyük yaş gruplarındaki öğrencilerle paralellik gösterdiği durumlar da bulunmaktadır. Hatta bazı sorularda 3. sınıf öğrencilerinin 4 ve 5. sınıf öğrencilerinden daha iyi performans gösterdiği görülmüştür. Örneğin $1,4,7,8$ ve 16 numaralı sorularda 3. sınıf öğrencileri 4. sınıf öğrencilerinden daha yüksek ortalamaya sahiptir. Bu durum daha küçük yaştaki ve sınıf düzeyindeki öğrencilerin mantıksal düşünme açısından daha büyük yaştaki/sınıf düzeyindeki öğrencilerden daha iyi performans gösterdiğinin bir kanıtıdır. Ortaya çıkan bu sonuç öğrencilerin bilişsel gelişim dönemlerinin eğitim ve kültür sürecinden etkilendiği (Holzman, 2009) ve uygun koşullar sağlanarak desteklenmesi şartıyla bir sonraki aşamaya geçilebileceği görüşü (Gelman, 1969) ile örtüşmektedir. Buna göre öğrencilere soyut işlemler dönemine gelmeleri beklenmeksizin uygun şekilde mantık eğitimi verildiğinde öğrencilerin mantıksal düşünme becerilerinin desteklenebileceği düşünülmektedir.

Gerek bu araştırmadna elde edilen sonuçlar gerekse alanyazında yapılan çalışmalar (Galotti, Komastu \& Volez, 1997; Hawkins ve diğ., 1984; Mandler \& McDonough, 1993; Richards ve Sanderson, 1999; Quinn, 2009; Quinn \& Eimas, 1996) göz önünde bulundurulduğunda, öğrencilerin var olan mantıksal düşünme becerilerinin salt ve formel mantık bilgisi çerçevesinde desteklenmesi için neden lise düzeyine kadar beklenildiği sorusu akla gelmektedir. Mantığın diğer disiplinlerle ilişkisi de göz önünde bulundurulduğunda farklı derslerde öğrencilerin mantıksal düşünme becerilerinin desteklenmesi durumu yadsınamaz. Ancak bağımsız olarak verilecek bir dersin istenilen verimliliğe ulaşabilme olasılığı daha yüksek olabilir. Örneğin matematik bilmenin amaçlarından birisi çocuğun günlük hayat problemlerine çözüm üretebilmesidir. Nasıl ki temel matematiksel işlemleri bilmeden çocukların doğrudan günlük hayatla ilişkili bağlamlar üzerinden matematik yapmasını beklemek zorsa temel mantık bilgisine sahip olmadan diğer disiplinlerde mantıksal düşüncenin desteklenmesinin eksik kalacağı düşünülmektedir. Bu maksatla mantık eğitiminin belli bir ders kapsamında ve formel mantık bilgisini içerecek şekilde verilmesiyle öğrencilerin erken 
yaşlardan itibaren sistematik düşünme, akıl yürütme, çıkarımda bulunma gibi becerileri desteklenebilir. Bu nedenle ortaöğretim mantık programı sınıf düzeyine ve yaş grubuna uygun öğretimsel düzenlemelerle birlikte ilkokulun son dönemlerinde ve ortaokul düzeyinde okutulabilir (Can, 2018). Bu uygulamanın hem öğrencilerin düşünme becerilerini geliştirmeye hem de diğer derslerdeki akademik başarılarını arttırmaya katkı sunacağı düşünülmektedir. Ayrıca yapılan çalışmalar okul öncesi dönemde de çocukların mantıksal düşünme becerilerini kullandıklarını göstermektedir (Mandler \& McDonough, 1993; Munakata, Casey \& Diamond, 2004; Spelke \& Kinzler, 2009). Bu sebeple okul öncesi dönemde çocukların mantıksal düşünme becerilerini tespit etmeye ve geliştirmeye yönelik uygulamalar yürütülebilir. $\mathrm{Bu}$ araştırmanın bir sonraki adımında, okul öncesi, ilkokul ve ortaokul öğrencilerinin mantıksal düşünme becerilerini geliştirmeye yönelik uygulamalar planlanarak deneysel araştırmalar yürütülebilir. Böylece mantık dersinin daha erken yaşlarda öğretim programlarına dahil edilmesi gerektiği yönünde sunulan önerilere daha somut kanıtlar getirilebilir. Küçük yaş grupları için hazırlanan mantık eğitimi uygulamalarının öğrencilerin mantıksal düşünme becerileri üzerindeki etkisi incelenerek eğitimcilere ve araştırmacılara yönelik örnekler sunulabilir.

\section{Makalenin Bilimdeki Konumu}

Eğitim Fakültesi/Sınıf Eğitimi Anabilim Dalı, Felsefe Bölümü/Mantık Anabilim Dalı

\section{Makalenin Bilimdeki Özgünlüğü}

Alanyazın incelendiğinde, öğrencilerin ve öğretmen adaylarının mantıksal düşünme becerilerinin incelenmesini konu alan çalışmalara rastlanmaktadır. Ancak bu çalışmalarda genellikle fen ve matematik alanlarındaki konular bağlamında hazırlanmış mantıksal düşünme becerilerini ölçmeye yönelik araçlar kullanılmıştır. Mantıksal düşünmenin gelişiminde salt mantık biliminin uygulamalarını içeren akıl ilkelerinin ve akıl yürütme yöntemlerinin bir araç olarak kullanılması oldukça önemlidir. $\mathrm{Bu}$ nedenle bu araştırma kapsamında salt mantık bilgisini içeren boyutlarda öğrencilerin mantıksal düşünme becerileri incelenmiştir. Ayrıca lise düzeyinde okutulmaya başlayan mantık dersini içeren konuların bağlamında hazırlanan bu test aracılığıyla 8-12 yaş aralığındaki öğrencilerin mantıksal düşünme becerileri değerlendirilmiştir. Elde edilen bulgular öğrencilerin mantıksal düşünme becerisini desteklemek amacıyla mantık dersinin daha erken dönemlerden itibaren verilmeye başlanması gerektiği yönündeki görüşlerimizi desteklemiştir.

\section{Kaynaklar}


Aksu, M., Berberoğlu, G., \& Paykoç, F. (1990). Can the GALT test be used in a different cultural setting? (Research Report). Ankara: METU.

Atılgan, H., Doğan, N., \& Kan, A. (2007). Eğitimde ölçme ve değerlendirme (2. baskı). Ankara: Anı Yayıncılık.

Aydeniz, M (2017, Ekim). Eğitim Sistemimiz ve 21. Yüzyıl Hayalimiz: 2045 Hedeflerine İlerlerken, Türkiye için STEM Odaklı Ekonomik Bir Yol Haritası. University of Tennessee, Knoxville.

Balanskat, A., \& Engelhardt, K. (2014). Computing our future: Computer programming and coding - Priorities, school curricula and initiatives across Europe. European Schoolnet. Çevrim-içi: http://www.eun.org/resources/detail?publicationID=481.

Baroody, A. J., Purpura, D. J., Eiland, M. D, \& Reid, E. E. (2015). The impact of highly and minimally guided discovery instruction on promoting the learning of reasoning strategies for basic add-1 and doubles combinations. Early Childhood Research Quarterly, 30, 93-105.

Boyd, M. P. (2015). Relations between teacher questioning and student talk in one elementary ELL classroom. Journal of Literacy Research, 47(3) 370-404, 10.1177/ $1086296 X 16632451$.

Büyüköztürk, Ş., Kılıç Çakmak, E., Akgün, Ö. E., Karadeniz, Ş., \& Demirel, F. (2012). Bilimsel Araştırma Yöntemleri. (18. Baskı). Ankara: Pegem Akademi.

Cam, P. (2014). Philosophy for Children, values education and the inquiring society. Educational Philosophy and Theory: Incorporating ACCESS, 46(11), 1203-1211, doi: 10.1080/00131857.2013.771443.

Can, V. (2018). Anadolu İmam Hatip Liselerindeki Mantık Eğitiminin Meslek Dersleri İle Ilişskisi ve Ilahiyat Fakültelerine Yansıması Üzerine Bir Araştırma. (Yayımlanmamış Yüksek Lisans Tezi), Süleyman Demirel Üniversitesi Sosyal Bilimler Enstitüsü, 2018.

Emiroğlu, İ. (2012). Klasik Mantığa Giriş. Ankara: Elis Yayınları.

European Commission (2014). Coding - the 21st century skill. European Commission. Çevrim-içi: https://ec.europa.eu/digital-single-market/coding-21st-century-skill.

Fraenkel, J. R., Wallen, N. E. \& Hyun, H. H. (2012). How to design and evaluate research in education. (8th ed). New York: McGraw-Hill.

Galotti, K. M., Komatsu, L. K., \& Voelz, S. (1997). Children's differential performance on deductive and inductive syllogisms. Developmental Psychology, 33, 70-78. 
Geban, Ö., Aşkar, P., \& Özkan, İ. (1992). Effects of computer simulated experiment and problem solving approaches on students' learning outcomes at the high school level. Journal of Educational Research, 86(1), 5-10.

Gelman, R. (1969). Conservation acquisition: A problem of learning to attend to relevant attributes. Journal of Experimental Child Psychology, 7, 167-187.

Hacıömeroğlu, E. S. \& Hacıömeroğlu, G. (2018). Öğretmen adaylarının mantıksal düşünme becerilerinin incelenmesi: Longeot bilişsel gelişim testi. Turkish Journal of Computer and Mathematics Education, 9(3), 413-448.

Hawkins, J., Pea, R. D., Glick, J., \& Scribner, S. (1984). “Merds that laugh don't like mushrooms": Evidence for deductive reasoning by preschoolers. Developmental Psychology, 20, 584-594.

Hingorjo, M. R., \& Jaleel, F. (2012). Analysis of one-best MCQs: The difficulty index, discrimination index and distractor efficiency. Journal of Pakistan Medical Association, 62(2), 142-147.

Holzman, L. (2009). Vygotsky at Work and Play. London and New York: Routledge.

Kıncal, R. Y. \& Yazgan, A. D. (2010). İlköğretim 7. ve 8. sınıf öğrencilerinin formal operasyonel düşünme becerilerinin bazı değişkenler açısından incelenmesi. İlköğretim Online, 9(2), 723-733.

Kline, R. B. (2005). Principles and practice of structural equation modeling. (2nd ed.). New York: The Guildford Press.

Lise Ders Programları, MEB Ortaöğretim Genel Müdürlüğü Yayınları, Ankara, 1998.

Lipman, M. (1973). Philosophy for children. Upper Montclair, New Jersey: Institute for the Advancement of Philosophy for Children, Montclair State College.

Mandler, J. M., \& McDonough, L. (1993). Concept formation in infancy. Cognitive Development, 8, 291-318.

Markovits H., Schleifer M., \& Fortier L. (1989). Development of elementary deductive reasoning in young children. Developmental Psychology, 25(5), 787-793. Doi: 10.1037/0012-1649.25.5.787.

MEB-TTKB (2015). Bilişim teknolojileri ve yazılım dersi programı. Talim Terbiye Kurulu Başkanlığı, Ankara. Çevrimiçi: http://ttkb.meb.gov.tr/

Moshman, D., \& Franks, B.A. (1986). Development of the concept of inferential validity. Educational Psychology Papers and Publications. Paper 53. 
Munakata, Y., Casey, B. J., \& Diamond, A. (2004). Developmental cognitive neuroscience: Progress and potential. Trends in Cognitive Sciences, 8, 122-128.

Özlem, D. (2012). Mantık (13.Bask1). İstanbul: Notos Kitap Yayınevi.

Partnership for 21st Century Skills (2009). Curriculum and instruction: A 21st century skills implementation guide. The Partnership for 21st Century Skill. Çevrim-içi: http://www.p21.org/storage/documents/p21- stateimp_curriculuminstruction.pdf.

Piaget, J. (1966). The psychology of intelligence (M. Pierce \& D. Berlyne, Trans.).NJ: Littlefield, Adams \& CO. (Original work published 1947).

Quinn, P. C. \& Eimas, P. D. (1996). Perceptual cues that permit categorical differentation of animal species by infants. Journal of Experimental Child Psychology, 63, 189-211.

Richards, C.A. \& Sanderson, J. A. (1999). The role of imagination in facilitating deductive reasoning in 2-, 3-, and 4-year-olds. Cognition 72, 81-89.

Santrock, J. W. (2011). Yaşam Boyu Gelişim (G. Yüksel, Çev. Ed.). Ankara: Nobel.

Säre, E., Luik, P., \& Tulviste, T. (2016). Improving pre-schoolers' reasoning skills using the Philosophy for Children programme. Trames: Journal of the Humanities and Social Sciences, 20(3), 273-295. Estonia: Estonian Academy Publishers, doi: 10.3176/tr.2016.3.03

Spelke, E. S., \& Kinzler, K. D. (2009). Innateness, learning, and rationality. Child Development Perspectives, 3(2), 96-98.http://dx.doi.org/10.1111/j.17508606.2009.00085.x

Tabachnick, G. B., \& Fidell, L. S. (2001). Using multivariate statistics. Needham Heights: Allyn \& Bacon, Inc.

Tavşancıl, E. (2005). Tutumların ölçülmesi ve SPSS ile veri analizi. Nobel Yayın Dağıtım, Ankara.

Yaman, S. ve Karamustafaoğlu, S. (2006). Öğretmen adaylarının mantıksal düşünme becerileri ve kimya dersine yönelik tutumlarının incelenmesi. Erzincan Ĕ̆itim Fakültesi Dergisi, 8(1), 91-106.

Yurdugül, H. (2005). Ölçek geliştirme çalışmalarında kapsam geçerliği için kapsam geçerlik indekslerinin kullanılması. XIV. Ulusal Eğitim Bilimleri Kongresi, 28-30 Eylül 2005. [Çevrim içi: http://yunus.hacettepe.edu.tr/ yurdugul/3/indir/PamukkaleBildiri.pdf, Erişim tarihi: 2 Ocak 2015.] 
Yüzüak, A. V. (2012). Lawson mantıksal düşünme testinin uyarlanması ve uygulanması. (Yayınlanmamış Yüksek Lisans Tezi). Gazi Üniversitesi, Eğitim Bilimleri Enstitüsü, Ankara.

\section{Summary}

\section{Statement of Problem}

The competencies required in the 21st century include such skills as investigative research, discussion, creative thinking, statistical thinking, using coding language and systematic thinking (Aydeniz, 2017). It is generally argued that the STEAM (Science, Technology, Engineering, Arts and Mathematics) practices involve these skills. First of all, the principles and methods of correct thinking must be taught to students to enable them to acquire these skills. Logic is defined as the knowledge of correct thinking rules and forms or the science of thinking laws and is one of the fields that may assist in teaching of correct thinking ways to students (Özlem, 2012). Although logic is a discipline and a course, it is at the same time a way of thinking. Logic is a discipline that sets out the rules and laws of logical thinking (Öner, 1982, p. 2-3; cited in Emiroğlu, 2012). Logic is concerned with the form of the kind of thinking, also called logical thinking, reasoning, reasoning, argumentation, and therefore, does not deal with all kinds of thinking (Özlem, 2012). Within the scope of this research, the functional definition of the concept of logic is defined by its ability to set the rules that provide the validity of reasoning and is expressed in terms of logical thinking or reasoning. In order to support and encourage the logical thinking skill it is significant to employ the principles of reasoning (identity, non-contradiction, the impossibility of the third state), reasoning methods (deduction, induction, analogy), concept and term, proposition, categorization (classification), inferences and comparisons of the applications of logic science.

In this study, it is aimed to examine how the logical thinking skills of elementary and middle school students vary based on the sub-dimensions of major logic subjects (reasoning, reasoning, concept-definition, classification-division) and on the variables of age and class level.

\section{Method}

In this research, a scanning design which is part of descriptive research is used. This specific research design was preferred since the aim of the research was to reveal the current situation. There are two groups of participants. The data of the pilot study were gathered from the group one and the data of the study were collected from the group two. The group one included 495 students attending primary schools and secondary schools in Burdur (56\% female 
and 44\% male). The group one included 348 students attending different primary schools and secondary schools in Burdur (48\% female and 52\% male). The logic test developed by the authors was used as data collection tool. In this framework, a test was developed to measure the students' logical thinking skills following the related studies were reviewed, and the validity and reliability analyses were completed following the pilot study. As a result of analyses, a structure consisting of 18 items and 4 dimensions was obtained. The structure obtained was found to have a valid consistency.

\section{Findings}

The aim of this study is to develop a test to measure the logical thinking skills of the students aged 8-12 and to examine how the performance of the students in the logic test changes depending on the variables of age and grade level. For this purpose, first the questions covering the principles of classical logic, reasoning methods, proposition, comparison, classification, division, definition and concept were developed, and the validity and reliability analyses were conducted. The findings indicate that the scale developed to measure the logical thinking skills of the students aged between 8 and 12 is consisted of the dimensions of principles of reasoning, reasoning methods, classification-division and definition-concept and that the logic test is both valid and reliable.

As a result of the research, it was determined that the students' logical thinking skills differ according to the sub-dimensions in the logic test. It is observed that the the students reach the highest average in the topics of non-contradiction and reasoning principles on the impossibility of the third state. The rate for the correct answers concerning the reasoning methods was found to be 55,5\%. The lowest level of student performance was observed in the concept-definition questions and the rate of the correct answers ranges between $36 \%$ and $50 \%$. The students' logical thinking skills increase depending on age. The performance of the participants in the logic test is significantly different between the 8-11, 8-12 and 9-11 age groups. This shows that 11-12 year-olds have higher logical thinking skills than students aged 8-9 years and that this difference is statistically significant. It was found that the performance of primary and secondary school students in the logic test differed significantly depending on the grade levels. According to the rank averages, the performance of 6th grade students is higher than the 5 th grade. This situation can be explained by the fact that the majority of the students in the 6th grade who are in the 11-12 age range have reached the abstract thinking process period.

\section{Discussion and Conclusion}


It is concluded that the development of logical thinking skills of students aged 8-9 years who were in the period of concrete thinking were significantly lower than the students of 1112 years old. However, it is seen that the logical thinking skills of the 8-9 year old students are in parallel with those of the students in the older age groups depending on the characteristics of the questions. This finding is consistent with the previous findings about the effects of education and culture on students' cognitive development (Holzman, 2009) and about the improvement of this development through proper conditions (Gelman, 1969). According to this, it is thought that the students' logical thinking skills can be supported when logic training is given developmentally appropriate there is no need to wait for students to reach the abstract process period. It is thought that if logic education will be given within the scope of a certain course and formal logic knowledge, it support students' skills such as systematic thinking, reasoning and inference from an early age. For this reason, the secondary school logic program can be taught at the end of primary school and at the middle school level with instructional arrangements appropriate for the class level and age group (Can, 2018). It is thought that this practice will contribute to improve students' thinking skills as well as to increase their academic achievement in other courses. Examples for educators and researchers can be presented by examining the effects of logic education practices towards small age groups on their logical thinking skills. 